\title{
The Effect of Informal Employment and Corruption on Income Levels in Brazil
}

\author{
Jamie Bologna \\ College of Business and Economics \\ West Virginia University \\ Morgantown, WV 26506-6025 \\ ph: 304-293-8533 \\ em : Jamie.Bologna@mail.wvu.edu
}

This version: August 2014

\begin{abstract}
This paper exploits a unique dataset on corruption and informal sector employment in 476 Brazilian municipalities to estimate whether corruption impacts GDP or income levels once variation in informal economic activity is taken into account. Overall, I find that higher levels of corruption and a larger informal economy are generally associated with poor economic outcomes. However, only the size of the informal economy has a statistically significant effect. This effect is robust to the inclusion of a variety of controls and fixed effects, as well as an instrumental variable analysis. Further, these effects are large in magnitude. For example, a one standard deviation increase in the share of total employees that are informally employed explains a decrease in GDP per-capita of about 18 percent.
\end{abstract}

Keywords: Corruption, informal economy, income levels, growth

JEL Codes: D73, O17, O43

Acknowledgements: I would like to thank Claudio Ferraz and Frederico Finan for kindly sharing their data. 


\section{Introduction}

Corruption is considered to be a major detriment to development, particularly in low-income countries. In a review of the literature, Olken and Pande (2012) summarize the ways in which corruption has been measured and show that no matter how dramatically the estimates differ there is a strong negative association between income levels and corruption. ${ }^{1}$ A major explanation for this finding is that corruption induces uncertainty, decreasing incentives for investment and thereby reducing growth (Shleifer and Vishny, 1993; Wei, 1997; Campos et al., 1999; Bologna, 2014).

An alternative, less direct, explanation of this finding is that corruption has an impact on the size of the informal sector (shadow economy) and the size of the informal sector subsequently impacts income levels and growth rates (La Porta and Shleifer, 2008). Specifically, in lower-income countries, corruption and the informal sector are found to be complements and therefore a higher level of corruption translates into a larger informal sector (Dreher and Schneider, 2010). Furthermore, it is highly plausible that the unofficial economy and the official economy are substitutes, rather than complements, in lower income countries causing the official economy to suffer when the unofficial economy is large (Dreher and Schneider, 2010; Johnson et al., 1997). Therefore, it could be the case that we see this strong negative association between low-income countries and high corruption levels partly because corruption is driving individuals to participate in the informal sector, seemingly lowering income and GDP per-capita due to its negative impact on the formal economy alone.

The negative relationship between corruption and income levels is well-documented, and numerous papers also link corruption to the size of the shadow economy (Johnson et al., 1997;

\footnotetext{
${ }^{1}$ This finding is common in much of the empirical literature (e.g., Li, Xu, and Zou, 2000; Abed and Davoodi, 2002; Treisman, 2007; Aidt, 2009).
} 
Hindriks et al., 1999; Hibbs and Piculescu, 2005; Dreher et al., 2009; Dreher and Schneider, 2010). However, empirical studies that explicitly incorporate the effect of the informal sector when estimating the relationship between corruption and economic outcomes at the aggregate level are scarce and there are virtually no studies that incorporate this effect within a specific country. ${ }^{2}$ For example, broad surveys of the corruption literature rarely mention the informal sector, other than the fact that its size may be influenced by corruption (e.g., Dreher and Herzfeld, 2005; Treisman, 2007). Thus, if the informal sector has a significant impact on economic outcomes and if corruption and the informal sector are significantly correlated, the previous empirical results are potentially biased. A primary contribution of this paper is to exploit a unique data set on corruption and informal sector employment in 476 Brazilian municipalities to estimate whether corruption impacts income levels once variation in informal economic activity is taken into account.

The size of the informal sector in Brazil is extremely large. Both employment and incomes from the informal sector are included in each decennial Census, making this an ideal country for this specific type of analysis. In the sample of municipalities used in this paper, the size of the Brazilian informal sector in 2000, as measured by share of employees without a formal contract, was over 50 percent of total employees. Furthermore, informal sector employees accounted for almost 40 percent of total income from employees of all types in these municipalities. Thus, it is clear that the informal sector is an integral part of the Brazilian economy.

\footnotetext{
${ }^{2}$ Dreher and Gassebner (2013) conduct a cross-sectional analysis and include the size of the informal sector in addition to corruption measures when examining how corruption impacts entrepreneurship, finding no change in their results. Wiseman (2014) argues that corruption only impacts entrepreneurship through its effect on the shadow economy within the United States, but does not include both effects in a single regression.
} 
In addition, corruption in Brazil has long been a serious problem. Due to a number of scandals exposing specific politician's behavior in the latter half of the $20^{\text {th }}$ century, Brazil is recognized as a country that is suffering from corrupt acts (Geddes and Neto, 1992; Silva, 1999). In order to combat corruption, in May of 2003, the government of Luiz Inácio Lula da Silva implemented a program based on random auditing of municipal governments' expenditures (Ferraz and Finan, 2008; Ferraz and Finan, 2011). This program randomly selects about one percent of the total number of municipalities with a population less than 500,000 (ControladoriaGeral da União (CGU)). The CGU auditors collect information on all federal funds transferred to the municipal government, inspects public work construction, and consults the population through community councils on any complaints of misconduct (CGU). This collected information is then organized into a report and made available to the public.

In a series of papers, Claudio Ferraz and Frederico Finan used these reports to construct measures of corruption in the audited municipalities $(2008 ; 2011)$. This paper uses the corruption indicators developed in their 2011 paper, specifically. Ferraz and Finan (2011) focus on three different types of corruption that could be found in these audit reports: fraud in the public procurement of goods and services, diversion of funds, and the over invoicing of goods and services. They estimate that corruption in these local governments alone amounts to be about $\$ 550$ million per year.

The main corruption variable of interest is the share of total federal resources ( $R$ \$) that is associated with any of these three types of corruption. As can be seen in figure 1, this corruption variable is negatively related to average incomes of both formal and informal workers. ${ }^{3}$ This figure also shows that, on average, formal employees have higher incomes than informal employees and that corruption has more of a negative impact on the informal sector than the

\footnotetext{
${ }^{3}$ Data will be explained in further detail in the data section.
} 
formal. Furthermore, as figure $\mathbf{2}$ shows, a higher level of corruption is associated with an increase in the size of the informal sector, although this positive relationship is relatively small in magnitude. Taken together, these figures suggest that even if corruption and the informal sector are complementary in the sense that corruption induces individuals to participate in the informal sector as in Dreher and Schneider (2010), these individuals are worse off regardless of being formally or informally employed in the presence of more corruption.

If the size of the informal sector has its own direct impact on the income levels of both the formally and informally employed, this could potentially bias the relationship between corruption and income levels. Some researchers argue that the official economy and the unofficial economy are complementary, and therefore an increase in the informal sector is not necessarily bad for economic growth (Choi and Thum, 2005). Schneider and Enste (2000) estimate that about two-thirds of the income earned in the informal sector is immediately spent in the formal economy, therefore causing there to be positive spillovers. However, others argue that reducing the shadow economy would lead to a significant increase in the tax base leading to higher quality public services and economic growth (Loayza, 1996). Researchers also argue that the informal sector distorts competition and prevents more efficient formal firms from gaining market share, consequently decreasing economic growth (Farrell, 2004).

La Porta and Shleifer (2008) summarize the above views of researchers into three broad categories: (1) a romantic view, (2) a parasitic view, and (3) a dual view. In regards to the first view, the informal sector consists of firms and individuals that are extremely similar in productivity (i.e., have similar characteristics) to the formal sector, however are only held back by governmental policies and practices. In this case, wages in both the formal sector and the informal sector would be fairly similar and a movement from the formal sector to the informal 
sector shouldn't have a large impact on the total amount produced. However, as shown in figure 1, formal employees earn more income on average. In addition, as shown in figure $\mathbf{3}$ municipalities with larger informal economies have lower levels of income in general. Thus, it is unlikely the case that the romantic view is the reality in Brazil.

The parasitic and dual views both argue that informal firms are far less productive than formal firms; however the parasitic view argues further that these informal firms actually have negative effects on the formal sector, while the dual view contends that these informal firms are far too small to have a negative impact on the formal sectors. Further, researchers that support the dual view believe that the informal sector is a good thing in developing countries as it gives individuals a type of refuge. La Porta and Shleifer (2008) find the most evidence in support of the dual view when looking at a cross-section of countries.

As can be seen in figure 3 , the size of the informal sector is negatively related to average incomes of both formal and informal workers, but has a stronger effect on the latter. The increase in the relative number of informal employees may be driving the wage down in the informal sector; however, all else equal this should also be increasing or leaving the wages in the formal sector unchanged, however the opposite is true. This is suggesting that the parasitic view may be the most relevant in Brazil. In the case of the Brazilian economy these informal, less productive, firms may actually take up a large enough share of the market to have a negative impact on the formal sector. In either case, it is clear that controlling for the size of the informal sector is important when estimating the relationship between corruption and income levels.

The relationships given in figures $\mathbf{1}$ through $\mathbf{3}$ are simply bivariate relationships, however, and may be excluding important factors. The goal of this paper is to closely examine these relationships, while controlling for a variety of factors that are found in the literature to 
have an impact on income levels. Specifically, I estimate how the level of corruption and the size of the informal sector impact GDP per-capita and both formal and informal income per-worker, while controlling for an additional 19 variables. Furthermore, I check the robustness of these results by including a variety fixed effects, as well as supplementing with an instrumental variable analysis.

As a preview of the results, this paper finds that while corruption tends to have a negative association with GDP per-capita and income levels, this relationship is largely statistically insignificant. However, the size of the informal sector has a negative and robustly significant relationship with GDP per-capita and average income from all sources of employment (both formal and informal). This is therefore suggesting that the size of the informal sector may be more important in determining income levels than corruption. Furthermore, even if informal employment is a relevant alternative to formal employment and results in positive spillovers into the formal economy, society as a whole is worse off in the face of a larger informal sector since both GDP per-capita and total incomes are lower.

A further review of the literature is described in 2; section 3 presents the data and empirical methodology; section 4 summarizes the results; section 5 concludes.

\section{Measuring Corruption and the Informal sector}

As emphasized in Olken and Pande (2012), the ideal way to measure corruption is by direct observation; however, due to corruption's secretive nature this is obviously difficult. Until recently, much of the literature on corruption has focused on cross-country comparisons between corruption perceptions and economic growth (e.g., Mauro, 1995). Nevertheless, these perception indices have been shown to be biased at both the macro level (Donchev and Ujhelyi, 2014) and 
at the micro level (Olken, 2009). Perceptions of corruption can easily be influenced by factors other than corruption, such as the level of incomes or education in each country. Furthermore, corruption perceptions are rather difficult to compare across countries. Given this, the use of more experience based measures of corruption has been emphasized at the aggregate level, the most common of which is an index of bribe payers (Treisman, 2007; Bologna, 2014).

However, while bribes represent a more direct measure of corruption, these aggregate measures are largely survey based and could still be biased. Given this, there have been several micro based studies that attempt to measure corruption through direct observation of bribes (e.g., McMillion and Zoido, 2004; Olken and Barron, 2009; Sequeria and Djankov, 2010) or by estimating theft of public resources (e.g., Reinikka and Svensson, 2004; Olken, 2007). However each of these micro based studies typically focuses on specific categories of public services such as education (Reinikka and Svensson, 2004) or public infrastructure (Olken, 2007).

The measure of corruption used in this paper is based on instances of corruption in Brazilian municipalities using audit reports that are made available to the public. This measure of corruption is unlikely to suffer from the biases of the perception indices, as it is estimating corruption from actual incidences of corruption. Furthermore, it is a much broader measure of corruption than bribes or theft of a specific type of government expenditure alone as it includes corruption in all types of government expenditures, rather than focusing on exclusive categories.

As explained in Ferraz and Finan (2011), Brazil is one of the most decentralized countries in the world, with local governments receiving about $\$ 35$ billion per year from the federal government to provide public services. The mayor and the local legislators are relatively free to decide how to spend these resources, allowing a great deal of room for corruption. The three most common ways in which local politicians can engage in corruption are fraud in the 
procurement in public services, diversion of funds, and over invoicing public services. As an example, Ferraz and Finan (2011) explain mayors often divert funds intended for public service projects, such as education, toward the purchases of personal items for either themselves or for their friends and family. ${ }^{4}$

Given the discretion allowed in the municipal governments, it is not surprising that there is a vast amount of corruption in the Brazilian municipalities. In order to combat this corruption, in May 2003, Luiz Inácio Lula da Silva implemented an anticorruption program based on random auditing of municipal expenditures. Out of a total of about 5,500 municipalities 50-60 are chosen to be audited on a monthly basis (CGU). Municipalities with more than 500,000 inhabitants cannot be chosen, therefore excluding approximately 8 percent of the municipalities (Ferraz and Finan, 2011). Furthermore, to ensure a fair and truly random process, individuals are invited to witness each lottery.

Once a municipality is chosen, approximately $10-15$ CGU auditors gather information on all federal funds transferred to the municipal government from 2001 onward. The results of each audit are made publicly available. Although the audit program is still in existence today, the dataset used in Ferraz and Finan (2011) uses audits only for the first eleven months of the program, or the first 11 lottery draws. Therefore, although Olken and Pande (2012) argue that the results of these audit reports need to be interpreted with caution as it represents both actual corruption and the inability to hide corruption from auditors, it unlikely that this would be a large issue using only the earliest audits, rather than the most recent ones.

As mentioned above, corruption is not the whole story when it comes to determining its effect on GDP and income levels. Although the literature is somewhat mixed as to the exact

\footnotetext{
${ }^{4}$ See Ferraz and Finan (2011) for further details on the political processes in Brazilian municipalities and for more examples of corruption occurring in these municipalities.
} 
direction of the relationship, corruption and the informal (shadow) economy are clearly related. Some argue that since the option of entering into the shadow economy can act as a constraint on politicians' behavior, corruption and the informal economy are substitutes for one another (Choi and Thum, 2005; Dreher et al., 2009). However, others argue that if the option of participating in the informal sector is plausible then corruption may drive entrepreneurs underground. In this case, corruption is often needed to expand the informal sector and therefore we may actually see that corruption and the informal sector are complementary (Johnson et al., 1997; Hindriks et al., 1999; Hibbs and Piculescu, 2005).

Dreher and Schneider (2010) argue that the relationship between corruption and the informal sector depends on the level of income or development of the specific country in question. Using the World Bank's definition of income classes, Dreher and Schneider (2010) break their sample up into two groups: low income and high income. Specifically, countries are classified as low income if their 2004 GNI per-capita is less than US $\$ 3,255$. Using this classification, Dreher and Schneider (2010) find that corruption and the informal sector are complements for countries in the low income group and substitutes for countries in the high income group.

Given that Brazil's 2004 GNI per-capita is approximately US \$3,310 (World Bank), Brazil is a country that just missed the low income cutoff point in the Dreher and Schneider (2010) analysis. From 2001 - 2003 the GNI per-capita in Brazil was actually less than the low income cutoff point of US $\$ 3,255$. Since the corruption data is measuring the level of corruption from 2001-2003, it is likely that Brazil falls into the low income group where corruption and the informal sector are complementary. Thus, in the case of Brazil it is likely that an increase in corruption corresponds to an increase in the size of the informal sector. 
Since the informal sector is likely to have its own impact on development (see, e.g., Schneider and Estne, 2000; La Porta and Shleifer, 2008), it is important to incorporate the informal sector into the analysis as well when looking at corruption-income level relationships. This leads to the question of how to properly measure the size of the informal sector. As noted in Schneider and Estne (2000), Schneider (2005), and Schneider (2007), a precise definition of the shadow, or informal, economy is still lacking. The informal sector includes both legal activities, such as unreported income related to the production of legal goods and services, as well as illegal activities, such as trade in stolen goods. A common working definition is to include all marketbased production of legal goods and services that are deliberately concealed from public authorities (see, e.g., Schneider and Williams, 2013). ${ }^{5}$

Given the availability of data in Brazil, this paper will use a slightly different, yet simpler, definition of the size of the informal sector. Each Brazilian Census includes data on all "types" of employees in the production of goods and services in all legal sectors of the economy- both formal and informal. Consistent with the definition used in the methodology of constructing GDP in Brazilian municipalities, this paper will define informal employees as the difference between the total number of employees and employees with a formal contract (Instituto Brasileiro de Geografia e Estatística - IBGE). Therefore, these informal employees are engaged in legal productive activities that contribute to the calculation of GDP; however, they are mostly non-tax payers. Specifically, only nine percent of employees without a formal contract are taxpayers of pension (IBGE). Thus, rather than using value-added estimates of these employees as the size of the informal sector, this paper will simply use the relative share of total

\footnotetext{
${ }^{5}$ As noted in Pederson (2003), it is important to understand that a portion of these unofficial activities are already incorporated into officially calculated national account measures so value estimates of the informal sector does not necessarily mean that the official measures are underestimated by exactly that amount.
} 
employment allocated to the informal sector. This gives a simple idea of how large the informal sector is in the Brazilian economy.

\section{Methodology \& Data}

The goal of this paper is to estimate the effect corruption has on economic outcomes, while incorporating the effects of the informal sector. This is done first using an estimate of GDP percapita in each municipality. However, given that the informal sector is unlikely to be fully incorporated into estimates of GDP, it is important to check the robustness of this result with total income from both formal and informal employment taken together, and with income from formal and informal employment separately. Therefore, this paper will estimate the following:

$$
y_{\mathrm{T}}=\alpha_{0}+\alpha_{1} C O R R U P T \_M E A S U R E+\alpha_{2} S I Z E \_I N F O R M A L+\theta X+\varepsilon,
$$

where $y_{\mathrm{T}}$ is either the log of GDP per-capita, total income per-worker from all types of employment, income per-worker from formal employment, or income per-worker from informal employment, CORRUPT_MEASURE is one of the two measures of corruption described in detail below, SIZE_INFORMAL is the relative share of total employees without a formal contract, $X$ is a matrix of additional controls, and $\varepsilon$ is the error term.

The data for this paper comes from three different sources: Instituto Brasileiro de Geografia e Estatística (Brazilian Institute of Geography and Statistics - IBGE), Instituto de Pesquisa Econômica Aplicada (Institute of Applied Economic Research - IPEA), and Ferraz and Finan (2011). All dependent variables and controls, other than the measure of corruption, come from either IBGE or IPEA. The corruption measures come from Ferraz and Finan (2011).

The first dependent variable of interest is simply GDP per-capita for each municipality put into R $\$ 2000$ dollars by the IPEA. Municipal GDP is calculated by the IBGE and made 
available by IPEADATA. This data is given annually from 2000 until 2010. Thus, since the corruption incidences that form the data of this paper take place mainly in 2001-2003, it makes sense to look at subsequent GDP per-capita levels in 2004. Furthermore, as corruption is often argued to have differing short-term and long-term relationships checking robustness with the most recent year available (2010) is also necessary (Aidt, 2009).

Looking at the relationships between GDP per-capita, corruption, and the informal sector will give some indication of how corruption and the informal sector influence official estimates of GDP. The estimates of GDP in each municipality explicitly includes value added in the construction industry from employees employed informally, accounting for approximately 70 percent of employment in that sector (IBGE). Thus, indicating that the IBGE is attempting to incorporate the informal sector into its official estimates. However, as mentioned in Pederson (2003), while official estimates of GDP are able to capture a portion of the informal sector, they are likely going to under-estimate "total" output if the size of the informal sector is significant. Since, on average, over 60 percent of employees fit the definition of informal as defined in this paper and in the GDP methodology, the GDP estimate is likely biased.

Therefore, these results are supplemented with average total income per-worker estimates that come from the IBGE Census in 2000 and in 2010. Total income is defined as the average yearly income employees, of any type, receive from their main job. Thus, this is a per-worker measure, rather than a strict per-capita measure. Furthermore, both the Census in 2000 and 2010 split this average income into several different types of employees. The incomes of the two types of employees that this paper is focused on are employees hired with a formal contract and those hired without a formal contract. The former are referred to as formal employees, and the latter are referred to as informal employees. As can be seen in table 1, in both 2000 and 2010, 
employees hired with a formal contract make almost double what those employees hired without a formal contract make. This paper will first estimate the relationship between corruption, the informal sector, and incomes in 2000, and then supplement these results with incomes in 2010. The latter estimates, as well as a supplemental IV analysis, will allow more causal arguments to be made.

The main corruption variable used in this paper, from Ferraz and Finan (2011), is defined as the share of audited resources (R\$) found to involve corruption (PROB_CORRUPT). This gives an idea of the proportion of federal resources that are involved in corrupt acts. However, since a dollar value was not available for every single instance of corrupt acts, Ferraz and Finan (2011) also use the share of audited items found to involve corruption (PROB_CORRUPT_2) as an alternative measure of corruption. This second measure gives an idea of the frequency of corrupt transactions, whereas the first measure gives more of an idea of how serious these transactions were, in terms of their value. As can be seen in table 1, there is a great amount of variation across municipalities in their levels of corruption. Approximately 6 percent of resources are found to involve corruption in the sample, however, this number gets as large as 80 percent of resources and as low as 0 percent of resources in some municipalities. Since not all municipalities in the sample were selected in the same lottery, lottery fixed effects are included in the regressions to check for robustness.

In addition to these main corruption variables, Ferraz and Finan (2011) develop an alternative measure of corruption associated with less blatant acts of corruption and more broadly inclusive of acts of mismanagement in general. They argue that these types of violations are less visible, yet may still be associated with acts of corruption. Essentially, any violation of a standard rule or procedure is recorded as an act of mismanagement. An example Ferraz and 
Finan (2011) give is in the procurement of public goods, at least three firms have to bid for the contract. When less than three firms bid, yet the good is still provided, this is coded as an act of mismanagement. To get a relative measure of mismanagement across municipalities, Ferraz and Finan (2011) divide the total number of violations by the total number of service items audited (MISMANAGE). ${ }^{6}$ This variable will be included in the regressions as a robustness check. If politicians do attempt to hide their blatant acts of corruption from the auditors, these acts are more likely to be uncovered using this variable.

As mentioned in the previous section the size of the informal sector will be defined as the difference between the total number of employees and the number of employees with a formal contract. ${ }^{7}$ This amount is then divided by the total number of employees so that we are measuring the relative size of the informal sector in each municipality (SIZE_INFORMAL). This definition is used because it is consistent with the construction of the GDP in each municipality (IBGE). Thus, this part of the informal sector is at least somewhat included in the official GDP estimates. Recall, the corruption variables represent corruption for the years 2001-2003. Therefore, given that the Census is available for years 2000 and 2010, this paper uses the size of the informal sector in 2000 as the control variable of interest. Thus, making SIZE_INFORMAL a predetermined variable in this model. Similarly, this paper includes an additional 18 variables to control for a variety of characteristics at or prior to the year of 2000 that are common in the literature (see, e.g., Higgins et al., 2006; Resende, 2013; Cravo and Resende, 2013). These variables include population and demographic controls (e.g., Resende, 2013), average years of

\footnotetext{
${ }^{6}$ Ferraz and Finan (2011) calculate this additional variable for only a subset of audited municipalities, dropping the total number of observations down to 331 .

${ }^{7}$ This definition of the informal sector includes military and public service employees, accounting for only about 17 percent of informal employment as defined in this paper (IBGE). Results do not change when excluding military and public service employees from the definition. For brevity, these results are not presented in this paper, but are available upon request.
} 
schooling (e.g., Cravo and Resende, 2013), and industrial employment structure (e.g., Higgins et al., 2006). An additional control is included to measure the cost of transport from each municipal headquarters to the city of São Paulo (Resende, 2013). This variable is included as São Paulo is essentially the center of economic activity in Brazil, and therefore is what most areas of Brazil depend on for development. All variable names, brief descriptions, and sources are given in table 1.

\section{Results}

For brevity, results are presented only for the main variables of interest (PROB_CORRUPT, PROB_CORRUPT_2, MISMANAGE, and SIZE_INFORMAL). Full results are available in the appendix. Table 2 and table 3 present the results for the first period of interest - the effect corruption and the informal sector have on GDP per-capita in 2004 as well as the relationship between corruption, the informal sector, and incomes in 2000. Specifications (1) through (4) include results without any fixed effects, while specifications (5) through (8) include state-level fixed effects and lottery number fixed effects.

As can be seen in these two tables, while the effect of corruption, as measured by either PROB_CORRUPT or PROB_CORRUPT_2, is negative in a majority of the specifications, it is largely statistically insignificant. Only in the case where corruption is measured by PROB_CORRUPT does corruption seem to have a negative and statistically significant association with GDP per-capita, however, this result is not robust to the inclusion of fixed effects. Furthermore, it appears that the inclusion of less blatant forms of corruption, MISMANAGE, has very little impact on the results. Furthermore, MISMANAGE is never statistically significant. 
However, the size of the informal sector (SIZE_INFORMAL) has a fairly robust, negative and statistically significant relationship with both GDP per-capita and total income levels. This is especially interesting since SIZE_INFORMAL also seems to have a positive relationship with formal income per-worker. Given its negative relationship with total income, this is suggesting that even if SIZE_INFORMAL results in positive spillovers to the formal sector, it has a negative overall impact on incomes.

In addition, the effects of SIZE_INFORMAL on GDP per-capita are large in magnitude. Considering only the statistically significant effects, a one standard deviation increase in the size of the informal sector is associated with a decrease in GDP per-capita of a maximum of about 18 percent to a minimum of about 13 percent, depending on the specification. The effects of the informal sector on total income levels are smaller in magnitude than their effects on GDP percapita, however the size of the effects are relatively stable across all specifications. A one standard deviation increase in the size of the informal sector is associated with a decrease in income per-worker of a maximum of about 8 percent to a minimum of about 7 percent.

This negative relationship, however, could be picking up the fact that as GDP falls, informal employment acts as a safety net in the short run even if its effects are negative in the long run therefore causing the share of informal employment to rise (Loayza and Rigolini, 2011). However, since we are looking at the effect the size of the informal sector in 2000 has on GDP per-capita in 2004, it is unlikely that this effect is exclusively picking up the business cycle effect. However, these results will be checked for robustness looking at the effect the size of the informal sector has on GDP per-capita after 10 years as well.

A similar story emerges when looking at the results from the second time period of interest, GDP per-capita in 2010 and income levels in 2010, presented in table 4 and table 5. 
The measures of corruption, $P R O B \_C O R R U P T$ and $P R O B \_C O R R U P T \_2$ have little relationship to GDP per-capita and income per-worker. As before, PROB_CORRUPT has a negative relationship with GDP per-capita that is not robust to the inclusion of state and lottery fixed effects. The major difference between the first time period and the time period given in tables 4 and $\mathbf{5}$ is that now when state and lottery fixed effects are included, $P R O B \_C O R R U P T \_2$ actually has a positive association with total incomes. Since PROP_CORRUPT_2 measures the frequency of corrupt transactions, this could be indicating that a "grease the wheels" situation is present (e.g., Leff, 1964; Huntington, 1968; Heckelman and Powell, 2010). In this case a higher frequency of corrupt transactions leads to higher income levels. However this effect is only positive and statistically significant in four of the 16 specifications using PROB_CORRUPT_2 in table 5.

Another major difference between the first period and the period presented in table $\mathbf{4}$ and 5 is that MISMANAGE seems to have more of an impact in the longer run. It seems that MISMANAGE has a statistically significant positive effect on formal income per-worker and a statistically significant negative effect on informal income per-worker. MISMANAGE still has no statistically significant relationship to total income per-worker or GDP per-capita in any case.

However, just as in table $\mathbf{2}$ and table $\mathbf{3}$, the size of the informal sector (SIZE_INFORMAL) exhibits a negative and statistically significant relationship to both GDP percapita and total income levels, although this effect is slightly smaller in magnitude. Thus, across both time periods, the size of the informal sector has a negative relationship with both GDP percapita and total income levels. This is robust to the inclusion of a variety of different corruption measures, as well as state and lottery fixed effects. It is possible, however, that the results are still suffering from omitted variable bias as some unobserved factor may be influencing both the 
size of the informal sector as well as GDP and income levels. Therefore, these results will be supplemented with an instrumental variable analysis.

A significant portion of informal employment in general fluctuates seasonally

(Hussmanns, 2004). More specifically, a lot of the informal employment that fluctuates seasonally is a result of tourism employment (Cukier and Wall, 1994). Furthermore, as argued in Loayza and Rigolini (2011) informal employment in the agricultural sector specifically may be more vulnerable to weather shocks than formal agriculture. Given that the agricultural industry alone makes up over a quarter of informal employment and that much of the non-agricultural informal employment is likely to fluctuate seasonally, it is likely that the size of the informal sector is going to be impacted by weather patterns in each municipality. Therefore, it seems reasonable to expect that the size of the informal sector is going to be dependent upon rainfall and temperature patterns during the summer months, Brazil's peak tourism period (December February).

IPEADATA provides quarterly measurements of both rainfall and temperature patterns across each municipality averaged over a thirty year period. This data is summarizing the weather patterns that were present in the municipalities for each season from 1961 -1990. This paper uses the summer period specifically as this is the peak period for tourism in Brazil and is part of the agricultural growing season. Thus, municipalities with climates more suitable to agricultural and attractive to tourists may be more likely to experience a large amount of informal employment.

Furthermore, it is reasonable to assume that average weather patterns from 1961 to 1990 are otherwise unrelated to GDP per-capita and total income levels. As described in Loayza and Rigolini (2011) the formal economy is less vulnerable to changes in weather patterns than the 
informal sector as the formal economy often has better access to technology. Thus, it is reasonable to assume that while the rain and temperature may impact the size of the informal sector, it has no direct impact on GDP per-capita and income levels.

As can be seen in table 6 in all cases the first stage F-statistics always reject the weak instrument null hypothesis according to the Stock and Yogo (2005) critical values and the Jstatistics indicate no evidence to reject the exogeneity of the instruments. Furthermore, the effect of SIZE_INFORMAL on GDP per-capita remains negative and statistically significant in every specification. However, the negative and statistically significant effect of SIZE_INFORMAL on total income per-worker disappears. In addition, PROB_CORRUPT still has a negative and statistically significant impact on GDP per-capita in both periods.

Thus, it appears that the size of the informal sector is negatively related to officially calculated GDP per-capita. This effect is robust to the inclusion of alternative corruption measures, a measurement of nonvisible corruption, and various fixed effects, as well as an instrumental variable analysis. Although this affect may be partially attributed to the fact that officially calculated GDP imperfectly includes the value added from the informal sector, the fact that the size of the informal sector also seems to be negatively related to total income per-worker leads to the conclusion that a larger informal sector leads to lower levels of actual output and incomes.

\section{Conclusion}

The negative association between average income levels and corruption is well documented. In addition, although the literature is mixed as to the exact direction of the relationship, the idea that corruption and the informal economy are highly connected is widely accepted as well. In 
particular, a common argument is that the informal economy and corruption are complementary to each other and therefore a higher amount of corruption will be associated with a larger informal economy. Moreover, a larger informal economy is also associated with lower levels of incomes. If this is the case, then it is plausible that the negative association documented between corruption and income levels may be partly due to the effect corruption has on the informal economy.

However, the empirical literature analyzing the links between corruption and income levels almost entirely ignores the effect of the informal economy. This paper exploits a unique data set on corruption and informal sector employment in 476 Brazilian municipalities to estimate whether corruption impacts GDP or income levels once variation in informal economic activity is taken into account. Overall, I find that both corruption and the informal economy are generally associated with poor economic outcomes. However, only the size of the informal economy has a robustly statistically significant effect.

Further, these effects are large in magnitude. For example, one standard deviation increase $(0.186)$ in the share of total employees that are informally employed is associated with a decrease in GDP per-capita of a maximum of about 18 percent to a minimum of about 13 percent, depending on the specification. Further, a one standard deviation increase in the size of the informal sector is associated with a decrease in income (both formal and informal) perworker of a maximum of about 8 percent to a minimum of about 7 percent. Given that the size of the informal economy varies from a minimum of about 13 percent to a maximum of 98 percent across municipalities in Brazil, these effects can be extremely large. Thus, the results indicate that the size of the informal economy may be more important for economic outcomes than corruption. 


\section{References}

Abed, G. T., Davoodi, H.R. 2002. Corruption, structural reforms, and economic performance in the transition economies. in (Abed and Gupta eds.) Governance, Corruption, and Economic Performance. Washington D.C.: International Monetary Fund.

Aidt, T. 2009. Corruption, institutions, and economic development. Oxford Review of Economic Policy 25, 271-291.

Bologna, J. 2014. Corruption: the good, the bad, and the uncertain. SSRN Working Paper (http://papers.ssrn.com/sol3/papers.cfm?abstract_id=2379061).

Campos, J., Lien, D., Pradhan, S. 1999. The impact of corruption on investment: predictability matters. World Development 27(6), 1059-1067.

Choi, J. P., Thum, M. 2005. Corruption and the shadow economy. International Economic Review 46(3), 817-836.

Cravo, T. A., Resende, G.M. 2014. Economic growth in Brazil: a spatial filtering approach. The Annals of Regional Science 50 (2), 555-575.

Cukier, J., Wall, G. 1994. Informal tourism employment: vendors in Bali, Indonesia. Tourism Management 15 (6), $464-467$.

Silva, M. F. 1999. The political economy of corruption in Brazil. Revista de Administração de Empresas 39(3), 26-41.

Donchev, D. and Ujhelyi, G. 2014. What do corruption indices measure? Economics and Politics 26(2), 309-331.

Dreher, A., Gassebner, M. 2013. Greasing the wheels? The impact of regulations and corruption on firm entry. Public Choice 155 (3-4), 413-432. 
Dreher, A., Herzfeld, T. 2005. The economic costs of corruption: a survey and new evidence. SSRN Working Paper (http://papers.ssrn.com/sol3/papers.cfm?abstract_id=734184).

Dreher, A., Kotsogiannis, C., McCorriston, S. 2009. How do institutions affect corruption and the shadow economy? International Tax and Public Finance 16 (6), 773-796.

Dreher, A., Schneider, F. 2010. Corruption and the shadow economy: an empirical analysis. Public Choice 144 (1), 215-238.

Farrell, D. 2004. The hidden dangers of the informal economy. McKinsey Quarterly 2004, 2637.

Ferraz, C., Finan, F. 2008. Exposing corrupt politicians: the effects of Brazil's publicly released audits on electoral outcomes. The Quarterly Journal of Economics 123(2), 703-745.

Ferraz, C., Finan, F. 2011. Electoral accountability and corruption: evidence from the audits of local governments. American Economic Review 101(4), 1274 - 1311.

Geddes, B., Neto, A.R. 1992. Institutional sources of corruption in Brazil. Third World Quarterly 13(4), 641-661.

Heckelman, J. C., Powell, B. 2010. Corruption and the institutional environment for growth. Comparative Economic Studies 52 (3), 351-378.

Hibbs, D. A., Jr., Piculescu, V. 2005. Institutions, corruption and tax evasion in the unofficial economy. Working Paper. Göteborg, University.

Higgins, M. J., Levy, D., Young, A. T. 2006. Growth and convergence across the US: Evidence from county-level data. Review of Economics and Statistics 88 (4), 671-681.

Hindriks, J., Keen, M., Muthoo, A. 1999. Corruption, extortion and evasion. Journal of Public Economics 74 (3), 395-430. 
Huntington, S. P. 1968. Political Order in Changing Societies. New York: Oxford University Press.

Hussmanns, R. 2005. Measuring the informal economy: from employment in the informal sector to informal employment. Policy Integration Department Working Paper No. 53, Bureau of Statistics International Labour Office, Geneva.

Johnson, S., Kaufmann, D., Shleifer, A. 1997. The unofficial economy in transition. Brookings Papers on Economic Activity 1997 (2), 159-239.

La Porta, R., Shleifer, A. 2008. The unofficial economy and economic development. NBER Working Paper Series No. 14520.

Leff, N. H. 1964. Economic development through bureaucratic corruption. The American Behavioral Scientist 8 (3), 8-14.

Li, H., Xu, L.C., Zou, H. 2000. Corruption, income distribution, and growth. Economics and Politics 12(2), 155-182.

Loayza, N. A. 1996. The economics of the informal sector: a simple model and some empirical evidence from Latin America. Carnegie-Rochester Conference Series on Public Policy $45,129-162$.

Loayza, N., Rigolini, J. 2011. Informal employment: safety net or growth engine? World Development 39 (9), 1503-1515.

Mauro, P. 1995. Corruption and growth. Quarterly Journal of Economics 110(3), 681-712.

Mcmillan, J., Zoido, P. 2004. How to subvert democracy: Montesinos in Peru. Journal of Economic Perspectives 18 (4), 69-92.

Olken, B. A. 2009. Corruption perceptions vs. corruption reality. Journal of Public Economics 93 (7-8), 950-964. 
Olken, B. A., 2007. Monitoring corruption: evidence from a field experiment in Indonesia. Journal of Political Economy 115 (2), 200-249.

Olken, B. A., Barron, P 2009. The simple economics of extortion: evidence from trucking in Aceh. Journal of Political Economy 117(3), 417- 452.

Olken, B. A., Pande, R. 2012. Corruption in developing countries. Annual Review of Economics 4, 479-509.

Pederson, S. 2003. The shadow economy in Germany, Great Britain, and Scandinavia: A measurement based on questionnaire surveys. Research Unit Study No. 5, The Rockwool Foundation Research Unit, Copenhagen.

Reinikka, R., Svensson, J. 2005. Fighting corruption to improve schooling: evidence from a newspaper campaign in Uganda. Journal of the European Economic Association 3 (2-3), 259-267.

Resende, G. M. 2013. Spatial dimensions of economic growth in Brazil. ISRN Economics 2013. http://dx.doi.org/10.1155/2013/398021.

Schneider, F. 2005 Shadow economies around the world: what do we really know? European Journal of Political Economy 21(3), 598-642.

Schneider, F. 2007. Shadow economies and corruption all over the world: new estimates for 145 countries. Economics: The Open-Access, Open-Assessment E-Journal 2007-9(2), 1-53. http://dx.doi.org/10.5018/economics-ejournal.ja.2007-9.

Schneider, F., Enste, D. H. 2000. Shadow economies: size, causes, and consequences. Journal of Economic Literature 38(1), 77-114.

Schneider, F., Williams, C.C. 2013. The Shadow Economy. London: The Institute of Economic Affairs. 
Sequeira, S., Djankov, S. 2010. An empirical study of corruption in ports. MPRA Paper 21791, University Library of Munich, Germany.

Shleifer, A., Vishny, R. W. 1993. Corruption. Quarterly Journal of Economics 108(3), 599-617.

Stock, J.H., Yogo, M. 2005. Testing for weak instruments in linear IV regression. NBER Technical Working Paper Series No. 284.

Treisman, D. 2007. What have we learned about the causes of corruption from ten years of crossnational empirical research? Annual Review of Political Science 10, 211-244.

Wei, S. 1997. Why is corruption so much more taxing than tax? Arbitrariness kills. NBER Working Paper No. 6255.

Wiseman, T. 2013. Entrepreneurship, Corruption, and the Size of the U.S. Underground Economies. SSRN Working Paper (http://papers.ssrn.com/sol3/papers.cfm?abstract_id=2219334). 
Figure 1: The relationship between corruption, as measured by the share of resources (R\$) found to involve corruption, and formal and informal incomes per-worker.
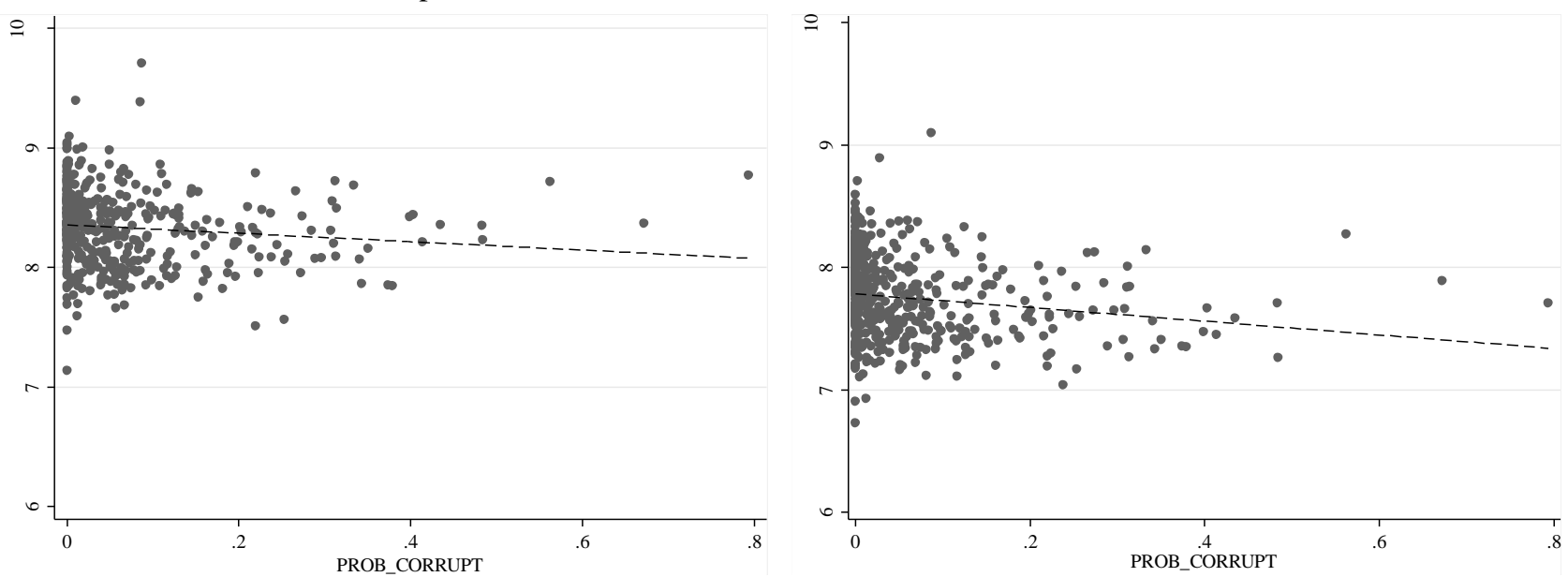

Sources: Formal and informal incomes per-capita (FORMAL_INCOME; INFORMAL_INCOME) from IBGE Census 2000 and the share of resources R $\$$ involving corruption (PROB_CORRUPT) from Ferraz and Finan (2011).

Figure 2: The relationship between corruption, as measured by the share of resources ( $\mathrm{R} \$$ ) found to involve corruption, and the size of the informal economy is 2000 .

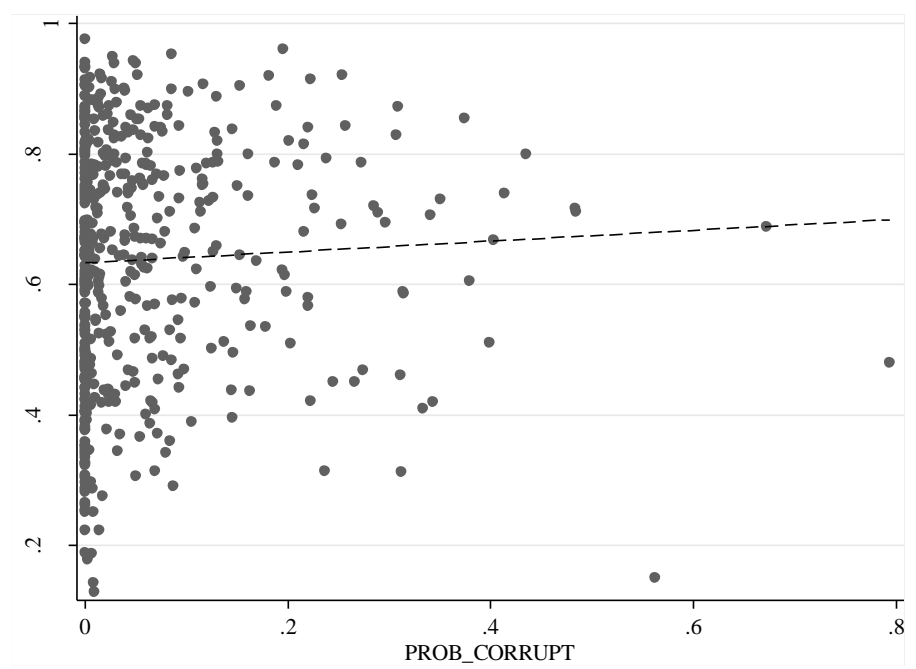

Sources: Size of informal economy (SIZE_INFORMAL), as measured by share of employees without a formal contract, from IBGE Census 2000 and the share of resources R\$ involving corruption (PROB_CORRUPT) from Ferraz and Finan (2011). 
Figure 3: The relationship between the size of the informal economy in 2000 and formal and informal incomes per-worker in 2000 .
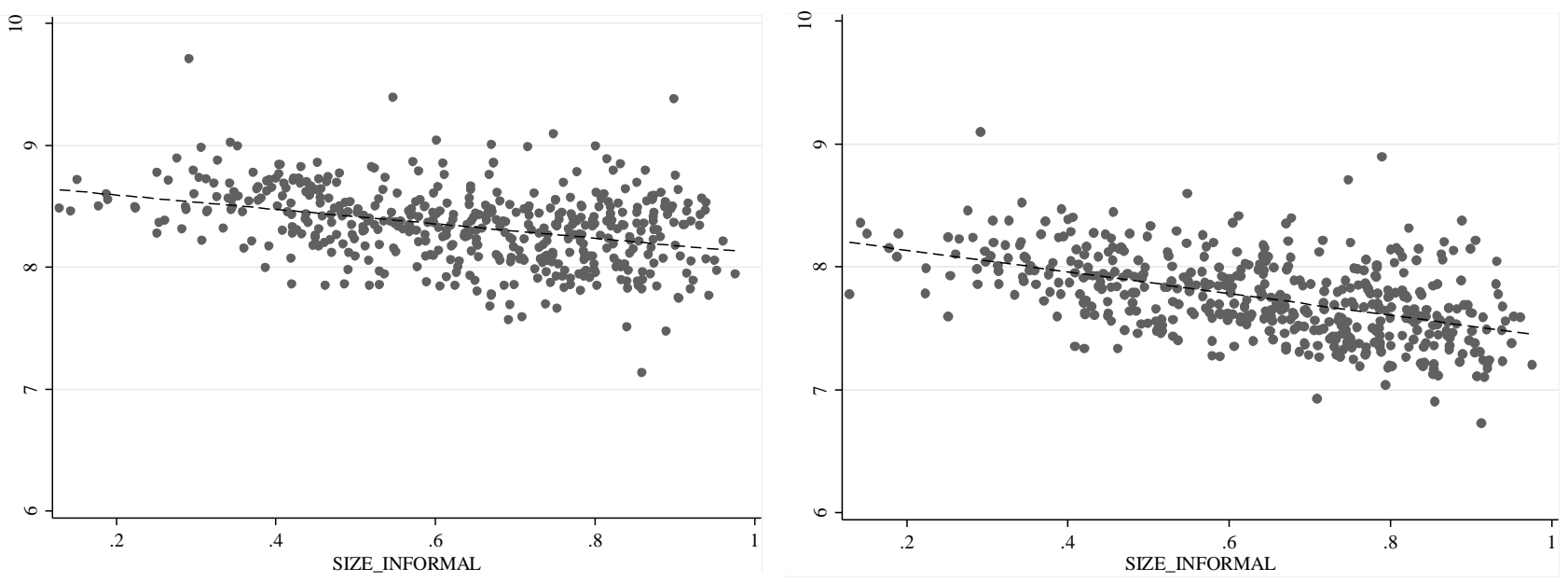

Sources: Formal and informal incomes per-capita (FORMAL_INCOME; INFORMAL_INCOME) as well as the size of the informal economy, as measured by SIZE_INFORMAL from IBGE Census 2000. 
Table 1: Summary statistics and brief variable descriptions.

\begin{tabular}{|c|c|c|c|c|c|c|c|c|}
\hline Variable & Description & Year & Source & Obs. & Mean & Std. Dev. & Min & Max \\
\hline \multicolumn{9}{|l|}{ Dependent Variables } \\
\hline$G D P \_P C \_04$ & GDP per-capita for years 2004. & 2004 & IPEADATA & 476 & 4819 & 7951 & 829 & 124638 \\
\hline$G D P_{-} P C_{-} 10$ & GDP per-capita for years 2010 . & 2010 & IPEADATA & 476 & 5904 & 9232 & 1055 & 129629 \\
\hline \multicolumn{9}{|l|}{ Types of Income } \\
\hline TOTAL_OO & Average yearly income per employees from main job. & 2000 & Census & 476 & 3497 & 1308 & 1311 & 14843 \\
\hline FORMAL_OO & Average yearly income per employees with formal contracts only. & 2000 & Census & 476 & 4369 & 1457 & 1257 & 16466 \\
\hline INFORMAL_OO & Average yearly income per employees without formal contracts only. & 2000 & Census & 476 & 2454 & 885 & 838 & 8927 \\
\hline TOTAL_10 & Average yearly income per employees from main job. & 2010 & Census & 476 & 4014 & 1157 & 2058 & 12804 \\
\hline FORMĀL_10 & Average yearly income per employees with formal contracts only. & 2010 & Census & 476 & 4612 & 1026 & 2718 & 13788 \\
\hline INFORMA $L_{-} 10$ & Average yearly income per employees without formal contracts only. & 2010 & Census & 476 & 2768 & 766 & 1363 & 7593 \\
\hline \multicolumn{9}{|c|}{ Independent Variables } \\
\hline PROB_CORRUPT & Share of audited resources $(\mathrm{R} \$)$ found to involve corruption. & 2001-04 & $\mathrm{F} \& \mathrm{~F}(2011)$ & 476 & 0.063 & 0.102 & 0.000 & 0.794 \\
\hline PROB_CORRUPT_2 & Share of audited items found to involve corruption. & 2001-04 & $\mathrm{F} \& \mathrm{~F}(2011)$ & 476 & 0.053 & 0.052 & 0.000 & 0.323 \\
\hline MISMANAGE & Proportion of irregularities associated with mismanagement. & 2001-04 & $\mathrm{F} \& \mathrm{~F}(2011)$ & 366 & 1.624 & 1.624 & 0.000 & 8.000 \\
\hline SIZE_INFORMAL & Share of total employees without a formal contract. & 2000 & Census & 476 & 0.639 & 0.186 & 0.129 & 0.977 \\
\hline POPULATION & Total population, enters regressions in logged form. & 2000 & Census & 476 & 25412 & 40598 & 1270 & 449476 \\
\hline URBAN & Share of urban population. & 2000 & Census & 476 & 0.601 & 0.231 & 0.119 & 1.000 \\
\hline DENSITY & People per square mile, enters regressions in logged form. & 2000 & Census & 476 & 320 & 2072 & 0.662 & 33,072 \\
\hline TEEN & Share of population between ages $10-19$ & 2000 & Census & 476 & 0.223 & 0.027 & 0.144 & 0.284 \\
\hline WORK & Share of population between ages $20-59$. & 2000 & Census & 476 & 0.473 & 0.052 & 0.336 & 0.579 \\
\hline ELDER & Share of population age 60 or over. & 2000 & Census & 476 & 0.088 & 0.026 & 0.031 & 0.214 \\
\hline SCHOOL & Average \# of years of schooling population 10 years or older. & 2000 & Census & 476 & 4.332 & 1.188 & 1.178 & 8.504 \\
\hline AGRICULTURE & Share of employment in agricultural sector. & 2000 & Census & 476 & 0.398 & 0.208 & 0.000 & 0.899 \\
\hline CONSTRUCTION & Share of employment in construction sector. & 2000 & Census & 475 & 0.055 & 0.031 & 0.003 & 0.284 \\
\hline MANUFACTURING & Share of employment in manufacturing sector. & 2000 & Census & 472 & 0.08 & 0.076 & 0.002 & 0.507 \\
\hline TRADE & Share of employment in trade sector. & 2000 & Census & 475 & 0.091 & 0.045 & 0.009 & 0.27 \\
\hline TRANSPORT & Share of employment in transportation sector. & 2000 & Census & 475 & 0.029 & 0.015 & 0.001 & 0.086 \\
\hline SERVICES & Share of employment in services sector. & 2000 & Census & 434 & 0.015 & 0.019 & 0.000 & 0.227 \\
\hline PROVISION & Share of employment in the provision of services sector. & 2000 & Census & 476 & 0.134 & 0.066 & 0.008 & 0.441 \\
\hline SOCIAL & Share of employment in the social services sector. & 2000 & Census & 475 & 0.077 & 0.03 & 0.030 & 0.203 \\
\hline GOVERNMENT & Share of employment in the government sector. & 2000 & Census & 476 & 0.054 & 0.035 & 0.035 & 0.278 \\
\hline OTHER & Share of employment in other activities sector. & 2000 & Census & 476 & 0.058 & 0.028 & 0.028 & 0.182 \\
\hline DISTANCE_SP & (Log) min. cost of transport to São Paulo Municipal Headquarters index & 1995 & IPEADATA & 476 & 1913 & 1311 & 68.063 & 8,582 \\
\hline \multicolumn{9}{|c|}{ Instrumental Variables } \\
\hline RAIN & Quarterly averages of rainfall of summer months Dec. - Feb. (mm). & $1961-90$ & IPEADATA & 433 & 119.652 & 41.491 & 36.723 & 240.050 \\
\hline TEMP & Quarterly averages of temperature of summer months Dec. - Feb. $\left({ }^{\circ} \mathrm{C}\right)$. & $1961-90$ & IPEADATA & 433 & 24.983 & 1.913 & 17.330 & 28.590 \\
\hline
\end{tabular}

Notes: All dependent variables enter regressions in logged form. 
Table 2: The effect corruption, as measured by the share of resources (R\$) found to involve corruption, and the informal economy have on GDP per-capita in 2004 and income per-capita from different sources in 2000.

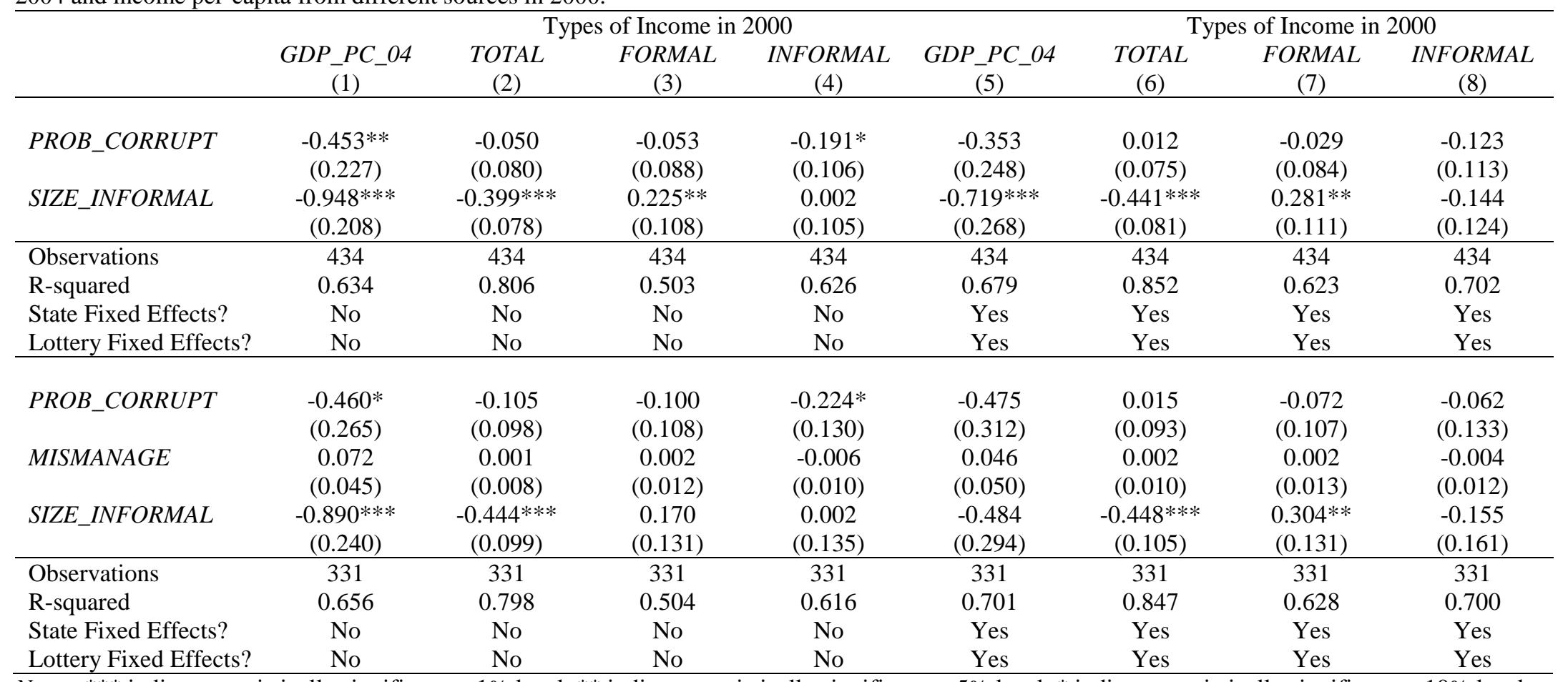

Notes: *** indicates statistically significant at $1 \%$ level, ** indicates statistically significant at 5\% level, * indicates statistically significant at $10 \%$ level. Standard errors are in parentheses. Constant included in all regressions. 
Table 3: The effect corruption, as measured by the share of items found to involve corruption, and the informal economy have on GDP per-capita and income per-capita from different sources in 2000.

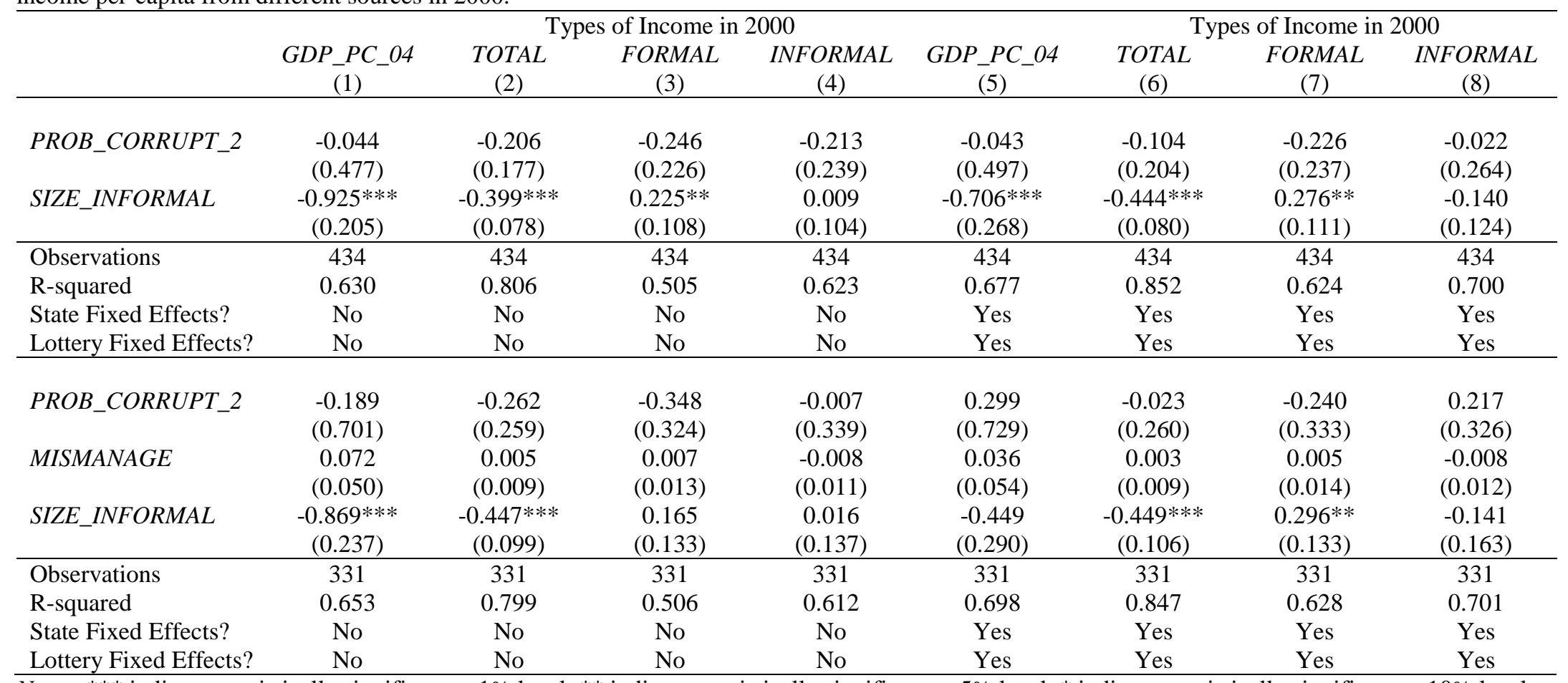

Notes: *** indicates statistically significant at $1 \%$ level, ** indicates statistically significant at 5\% level, * indicates statistically significant at $10 \%$ level. Standard errors are in parentheses. Constant included in all regressions. 
Table 4: The effect corruption, as measured by the share of resources (R $\$$ ) found to involve corruption, and the informal economy have on GDP per-capita and income per-capita from different sources in 2010.

\begin{tabular}{|c|c|c|c|c|c|c|c|c|}
\hline & \multicolumn{5}{|c|}{ Types of Income in 2010} & \multicolumn{3}{|c|}{ Types of Income in 2010} \\
\hline & $\begin{array}{c}G D P_{-} P C_{-} 10 \\
(1)\end{array}$ & $\begin{array}{l}\text { TOTAL } \\
\quad(2) \\
\end{array}$ & $\begin{array}{c}\text { FORMAL } \\
\text { (3) }\end{array}$ & $\begin{array}{c}\text { INFORMAL } \\
(4)\end{array}$ & $\begin{array}{c}G D P_{-} P C_{-} 10 \\
(5)\end{array}$ & $\begin{array}{l}\text { TOTAL } \\
(6) \\
\end{array}$ & $\begin{array}{c}\text { FORMAL } \\
(7) \\
\end{array}$ & $\begin{array}{c}\text { INFORMAL } \\
(8) \\
\end{array}$ \\
\hline PROB_CORRUPT & $\begin{array}{c}-0.499 * * \\
(0.211)\end{array}$ & $\begin{array}{c}0.006 \\
(0.054)\end{array}$ & $\begin{array}{c}-0.061 \\
(0.069)\end{array}$ & $\begin{array}{l}-0.049 \\
(0.148)\end{array}$ & $\begin{array}{c}-0.311 \\
(0.214)\end{array}$ & $\begin{array}{l}-0.003 \\
(0.051)\end{array}$ & $\begin{array}{l}-0.085 \\
(0.065)\end{array}$ & $\begin{array}{c}0.131 \\
(0.103)\end{array}$ \\
\hline SIZE_INFORMAL & $\begin{array}{c}-0.861 * * * \\
(0.207) \\
\end{array}$ & $\begin{array}{c}-0.324 * * * \\
(0.060) \\
\end{array}$ & $\begin{array}{l}-0.025 \\
(0.069) \\
\end{array}$ & $\begin{array}{l}-0.102 \\
(0.131) \\
\end{array}$ & $\begin{array}{c}-0.638 * * \\
(0.265) \\
\end{array}$ & $\begin{array}{c}-0.263^{* * * *} \\
(0.065) \\
\end{array}$ & $\begin{array}{c}0.096 \\
(0.074) \\
\end{array}$ & $\begin{array}{c}-0.256^{* *} \\
(0.126) \\
\end{array}$ \\
\hline Observations & 434 & 434 & 434 & 434 & 434 & 434 & 434 & 434 \\
\hline R-squared & 0.615 & 0.803 & 0.522 & 0.552 & 0.665 & 0.854 & 0.633 & 0.801 \\
\hline State Fixed Effects? & No & No & No & No & Yes & Yes & Yes & Yes \\
\hline Lottery Fixed Effects? & No & No & No & No & Yes & Yes & Yes & Yes \\
\hline PROB_CORRUPT & $\begin{array}{l}-0.421 * \\
(0.235)\end{array}$ & $\begin{array}{l}-0.017 \\
(0.063)\end{array}$ & $\begin{array}{l}-0.100 \\
(0.080)\end{array}$ & $\begin{array}{l}-0.118 \\
(0.169)\end{array}$ & $\begin{array}{l}-0.303 \\
(0.266)\end{array}$ & $\begin{array}{c}-0.012 \\
(0.058)\end{array}$ & $\begin{array}{c}-0.129 * \\
(0.077)\end{array}$ & $\begin{array}{c}0.230 \\
(0.141)\end{array}$ \\
\hline MISMANAGE & $\begin{array}{c}0.055 \\
(0.035)\end{array}$ & $\begin{array}{l}-0.001 \\
(0.006)\end{array}$ & $\begin{array}{l}0.013^{*} \\
(0.007)\end{array}$ & $\begin{array}{c}-0.043 * * * \\
(0.014)\end{array}$ & $\begin{array}{c}0.029 \\
(0.039)\end{array}$ & $\begin{array}{c}0.005 \\
(0.008)\end{array}$ & $\begin{array}{c}0.024 * * * \\
(0.008)\end{array}$ & $\begin{array}{c}-0.026^{*} \\
(0.014)\end{array}$ \\
\hline SIZE_INFORMAL & $\begin{array}{c}-0.839 * * * \\
(0.235)\end{array}$ & $\begin{array}{c}-0.379 * * * \\
(0.071)\end{array}$ & $\begin{array}{l}-0.089 \\
(0.083) \\
\end{array}$ & $\begin{array}{l}-0.003 \\
(0.147)\end{array}$ & $\begin{array}{l}-0.441 \\
(0.286)\end{array}$ & $\begin{array}{c}-0.266 * * * \\
(0.080)\end{array}$ & $\begin{array}{c}0.082 \\
(0.089)\end{array}$ & $\begin{array}{l}-0.190 \\
(0.137) \\
\end{array}$ \\
\hline Observations & 331 & 331 & 331 & 331 & 331 & 331 & 331 & 331 \\
\hline R-squared & 0.656 & 0.800 & 0.512 & 0.555 & 0.707 & 0.855 & 0.655 & 0.803 \\
\hline State Fixed Effects? & No & No & No & No & Yes & Yes & Yes & Yes \\
\hline Lottery Fixed Effects? & No & No & No & No & Yes & Yes & Yes & Yes \\
\hline
\end{tabular}

Notes: *** indicates statistically significant at $1 \%$ level, ** indicates statistically significant at 5\% level, * indicates statistically significant at $10 \%$ level. Standard errors are in parentheses. Constant included in all regressions. 
Table 5: The effect corruption, as measured by the share of items found to involve corruption, and the informal economy have on GDP per-capita and income per-capita from different sources in 2010.

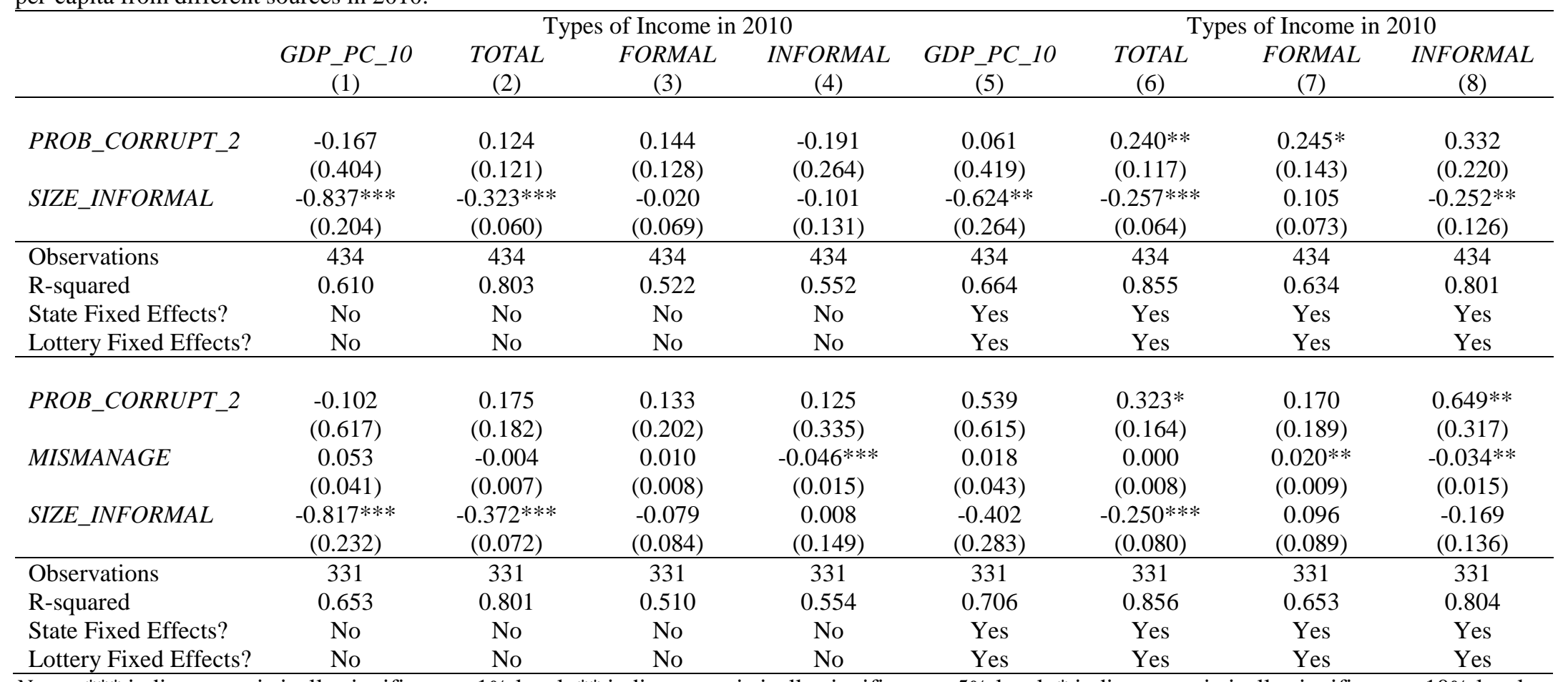

Notes: *** indicates statistically significant at $1 \%$ level, ** indicates statistically significant at 5\% level, * indicates statistically significant at $10 \%$ level. Standard errors are in parentheses. Constant included in all regressions. 
Table 6: The effect corruption and the informal economy have on GDP per-capita and total income per-capita in 2000 and 2010 IV robustness checks.

\begin{tabular}{|c|c|c|c|c|c|c|c|c|}
\hline & $G D P \_P C \_04$ & TOTAL_OO & $G D P \_P C \_04$ & TOTAL_OO & $G D P \_P C_{-} 10$ & TOTAL_10 & $G D P \_P C \_10$ & TOTAL_10 \\
\hline PROB_CORRUPT & $\begin{array}{c}-0.415^{* *} \\
(0.205)\end{array}$ & $\begin{array}{c}0.037 \\
(0.093)\end{array}$ & & & $\begin{array}{c}-0.461 * * \\
(0.200)\end{array}$ & $\begin{array}{c}0.053 \\
(0.064)\end{array}$ & & \\
\hline PROB_CORRUPT_2 & & & $\begin{array}{c}-0.106 \\
(0.503)\end{array}$ & $\begin{array}{c}-0.094 \\
(0.209)\end{array}$ & & & $\begin{array}{c}-0.304 \\
(0.421)\end{array}$ & $\begin{array}{c}0.154 \\
(0.135)\end{array}$ \\
\hline SIZE_INFORMAL & $\begin{array}{c}-1.543 * * * \\
(0.545)\end{array}$ & $\begin{array}{c}0.273 \\
(0.248) \\
\end{array}$ & $\begin{array}{c}-1.554 * * * \\
(0.542)\end{array}$ & $\begin{array}{c}0.284 \\
(0.247) \\
\end{array}$ & $\begin{array}{c}-1.152 * * \\
(0.519) \\
\end{array}$ & $\begin{array}{c}-0.014 \\
(0.192) \\
\end{array}$ & $\begin{array}{c}-1.145 * * \\
(0.517)\end{array}$ & $\begin{array}{l}-0.027 \\
(0.191)\end{array}$ \\
\hline Observations & 404 & 404 & 404 & 404 & 404 & 404 & 404 & 404 \\
\hline R-squared & 0.639 & 0.766 & 0.636 & 0.764 & 0.628 & 0.789 & 0.625 & 0.790 \\
\hline J-Statistic & 0.321 & 0.394 & 0.369 & 0.332 & 0.173 & 0.672 & 0.192 & 0.755 \\
\hline F-Statistic & $22.437 * * *$ & $22.437 * * *$ & $22.206^{* * * *}$ & $22.206 * * *$ & $22.437 * * *$ & $22.437 * * *$ & $22.206 * * *$ & $22.206 * * *$ \\
\hline
\end{tabular}

Notes: $* * *$ indicates statistically significant at $1 \%$ level, $* *$ indicates statistically significant at $5 \%$ level, $*$ indicates statistically significant at $10 \%$ level. Standard errors are in parentheses. SIZE_INFORMAL is instrumented for with RAIN and TEMP. Constant included in all regressions. 


\section{Appendix}

Table A1: The effect corruption, as measured by the share of audited resources (R\$) found to involve corruption, and the informal economy has on GDP per-capita and income per-capita from different sources.

\begin{tabular}{|c|c|c|c|c|}
\hline & & & of Income is & \\
\hline & $G D P \_P C \_04$ & TOTAL & FORMAL & INFORMAL \\
\hline PROB_CORRUPT & $-0.453 * *$ & -0.050 & -0.053 & $-0.191 *$ \\
\hline & $(0.227)$ & $(0.080)$ & $(0.088)$ & $(0.106)$ \\
\hline SIZE_INFORMAL & $-0.948 * * *$ & $-0.399 * * *$ & $0.225 * *$ & 0.002 \\
\hline & $(0.208)$ & $(0.078)$ & $(0.108)$ & $(0.105)$ \\
\hline POPULATION & 0.017 & $0.050 * * *$ & $0.086 * * *$ & 0.016 \\
\hline & $(0.042)$ & $(0.013)$ & $(0.017)$ & $(0.019)$ \\
\hline$U R B A N$ & -0.068 & $-0.152 * *$ & -0.116 & -0.082 \\
\hline & $(0.208)$ & $(0.067)$ & $(0.091)$ & $(0.088)$ \\
\hline SCHOOL & $0.196 * * *$ & $0.202 * * *$ & $0.173 * * *$ & $0.131 * * *$ \\
\hline & $(0.052)$ & $(0.020)$ & $(0.026)$ & $(0.025)$ \\
\hline DENSITY & $-0.118 * * *$ & $-0.059 * * *$ & $-0.057 * * *$ & $-0.048 * * *$ \\
\hline & $(0.029)$ & $(0.009)$ & $(0.012)$ & $(0.013)$ \\
\hline DISTANCE_SP & 0.009 & $-0.048 * * *$ & $-0.038 *$ & $-0.061 * * *$ \\
\hline & $(0.050)$ & $(0.016)$ & $(0.019)$ & $(0.021)$ \\
\hline TEEN & $-4.563 *$ & $-4.189 * * *$ & -2.121 & $-5.383 * * *$ \\
\hline & $(2.400)$ & $(0.882)$ & $(1.344)$ & $(1.045)$ \\
\hline WORK & $4.431 * * *$ & $-1.635 * * *$ & -0.905 & $-1.267 * *$ \\
\hline & $(1.253)$ & $(0.485)$ & $(0.725)$ & $(0.613)$ \\
\hline$E L D E R$ & $-6.061 * * *$ & $-4.090 * * *$ & $-2.695 * * *$ & $-5.766 * * *$ \\
\hline & $(1.270)$ & $(0.429)$ & $(0.613)$ & $(0.540)$ \\
\hline AGRICULTURE & -0.404 & -0.078 & -0.723 & 0.653 \\
\hline & $(1.349)$ & $(0.534)$ & $(1.047)$ & $(0.510)$ \\
\hline CONSTRUCTION & 1.380 & 0.412 & 0.123 & 1.052 \\
\hline & $(1.848)$ & $(0.680)$ & $(1.217)$ & $(0.786)$ \\
\hline MANUFACTURING & -0.041 & -0.192 & -0.575 & $0.894 *$ \\
\hline & $(1.381)$ & $(0.532)$ & $(1.049)$ & $(0.509)$ \\
\hline$T R A D E$ & -1.744 & 0.217 & -0.570 & $1.121 *$ \\
\hline & $(1.563)$ & $(0.571)$ & $(1.020)$ & $(0.618)$ \\
\hline TRANSPORT & 0.405 & 1.304 & 0.532 & $2.140 *$ \\
\hline & $(2.500)$ & $(0.917)$ & $(1.417)$ & $(1.138)$ \\
\hline SERVICES & 0.573 & 0.377 & -0.351 & 0.984 \\
\hline & $(2.218)$ & $(0.747)$ & $(1.289)$ & $(0.764)$ \\
\hline PROVISION & -0.694 & -0.733 & -1.602 & 0.080 \\
\hline & $(1.498)$ & $(0.585)$ & $(1.090)$ & $(0.600)$ \\
\hline SOCIAL & 0.211 & 0.702 & 0.008 & 0.957 \\
\hline & $(1.748)$ & $(0.664)$ & $(1.254)$ & $(0.712)$ \\
\hline GOVERNMENT & 0.508 & 0.007 & -0.715 & 0.576 \\
\hline & $(1.677)$ & $(0.583)$ & (1.118) & $(0.618)$ \\
\hline OTHER & -2.168 & -0.030 & -0.524 & 1.027 \\
\hline & $(1.657)$ & $(0.642)$ & (1.111) & $(0.669)$ \\
\hline Observations & 434 & 434 & 434 & 434 \\
\hline R-squared & 0.634 & 0.806 & 0.503 & 0.626 \\
\hline
\end{tabular}


Table A2: The effect corruption, as measured by the share of audited resources (R\$) found to involve corruption, and the informal economy has on GDP per-capita and income per-capita from different sources.

\begin{tabular}{|c|c|c|c|c|}
\hline & & & of Income i & \\
\hline & GDP_PC_04 & TOTAL & FORMAL & INFORMAL \\
\hline PROB_CORRUPT & $-0.460^{*}$ & -0.105 & -0.100 & $-0.224 *$ \\
\hline & $(0.265)$ & (0.098) & $(0.108)$ & $(0.130)$ \\
\hline MISMANAGE & 0.072 & 0.001 & 0.002 & -0.006 \\
\hline & $(0.045)$ & $(0.008)$ & $(0.012)$ & $(0.010)$ \\
\hline SIZE_INFORMAL & $-0.890 * * *$ & $-0.444 * * *$ & 0.170 & 0.002 \\
\hline & $(0.240)$ & (0.099) & $(0.131)$ & $(0.135)$ \\
\hline POPULATION & 0.012 & $0.058 * * *$ & $0.100 * * *$ & 0.019 \\
\hline & $(0.041)$ & $(0.016)$ & $(0.021)$ & $(0.022)$ \\
\hline$U R B A N$ & -0.046 & $-0.165^{* *}$ & $-0.186^{*}$ & -0.043 \\
\hline & $(0.234)$ & $(0.076)$ & $(0.101)$ & $(0.108)$ \\
\hline SCHOOL & $0.199 * * *$ & $0.191 * * *$ & $0.146 * * *$ & $0.125^{* * *}$ \\
\hline & $(0.055)$ & $(0.024)$ & $(0.031)$ & $(0.030)$ \\
\hline DENSITY & $-0.129 * * *$ & $-0.060 * * *$ & $-0.055 * * *$ & $-0.051 * * *$ \\
\hline & $(0.033)$ & $(0.011)$ & $(0.014)$ & $(0.015)$ \\
\hline DISTANCE_SP & -0.019 & $-0.054 * * *$ & $-0.048 * *$ & $-0.070 * * *$ \\
\hline & $(0.060)$ & (0.019) & $(0.023)$ & $(0.025)$ \\
\hline TEEN & $-4.771^{*}$ & $-4.660 * * *$ & -2.385 & $-5.450 * * *$ \\
\hline & $(2.650)$ & (1.038) & $(1.616)$ & $(1.256)$ \\
\hline WORK & $4.489 * * *$ & $-1.647 * * *$ & -0.526 & $-1.362^{*}$ \\
\hline & $(1.376)$ & $(0.558)$ & $(0.860)$ & $(0.724)$ \\
\hline ELDER & $-5.862 * * *$ & $-4.249 * * *$ & $-2.921 * * *$ & $-5.827 * * *$ \\
\hline & $(1.350)$ & $(0.542)$ & (0.777) & $(0.682)$ \\
\hline AGRICULTURE & -1.413 & -0.666 & $-2.590 * *$ & 1.066 \\
\hline & (2.028) & $(0.888)$ & (1.013) & $(0.739)$ \\
\hline CONSTRUCTION & -1.173 & -0.294 & -2.093 & 1.841 \\
\hline & $(2.752)$ & (1.136) & $(1.284)$ & (1.137) \\
\hline MANUFACTURING & -1.196 & -0.855 & $-2.448 * *$ & $1.230^{*}$ \\
\hline & (2.067) & $(0.879)$ & $(1.016)$ & $(0.719)$ \\
\hline$T R A D E$ & -1.869 & -0.346 & $-2.205 * *$ & $1.518 *$ \\
\hline & (2.134) & $(0.891)$ & (1.014) & $(0.825)$ \\
\hline TRANSPORT & -2.154 & 0.804 & -1.703 & $2.925 * *$ \\
\hline & $(3.145)$ & $(1.273)$ & $(1.480)$ & $(1.436)$ \\
\hline SERVICES & 1.438 & -0.265 & $-2.476^{*}$ & 1.505 \\
\hline & $(3.857)$ & (1.198) & $(1.414)$ & $(1.229)$ \\
\hline PROVISION & -1.784 & -1.415 & $-3.547 * * *$ & 0.307 \\
\hline & $(2.159)$ & $(0.935)$ & $(1.086)$ & $(0.857)$ \\
\hline SOCIAL & -0.474 & 0.028 & -1.783 & 1.087 \\
\hline & $(2.492)$ & $(1.051)$ & $(1.263)$ & $(0.975)$ \\
\hline GOVERNMENT & -0.621 & -0.490 & $-2.689 * *$ & 1.066 \\
\hline & $(2.282)$ & $(0.922)$ & (1.107) & $(0.798)$ \\
\hline OTHER & -2.576 & -0.522 & $-2.274 * *$ & 1.391 \\
\hline & $(2.354)$ & $(1.009)$ & $(1.156)$ & $(0.872)$ \\
\hline Observations & 331 & 331 & 331 & 331 \\
\hline R-squared & 0.656 & 0.798 & 0.504 & 0.616 \\
\hline
\end{tabular}

Notes: *** indicates statistically significant at $1 \%$ level, ** indicates statistically significant at $5 \%$ level, $*$ indicates statistically significant at $10 \%$ level. Standard errors are in parentheses. Constant included in all regressions. 
Table A3: The effect corruption, as measured by the share of audited resources (R\$) found to involve corruption, and the informal economy has on GDP per-capita and income per-capita from different sources with fixed effects.

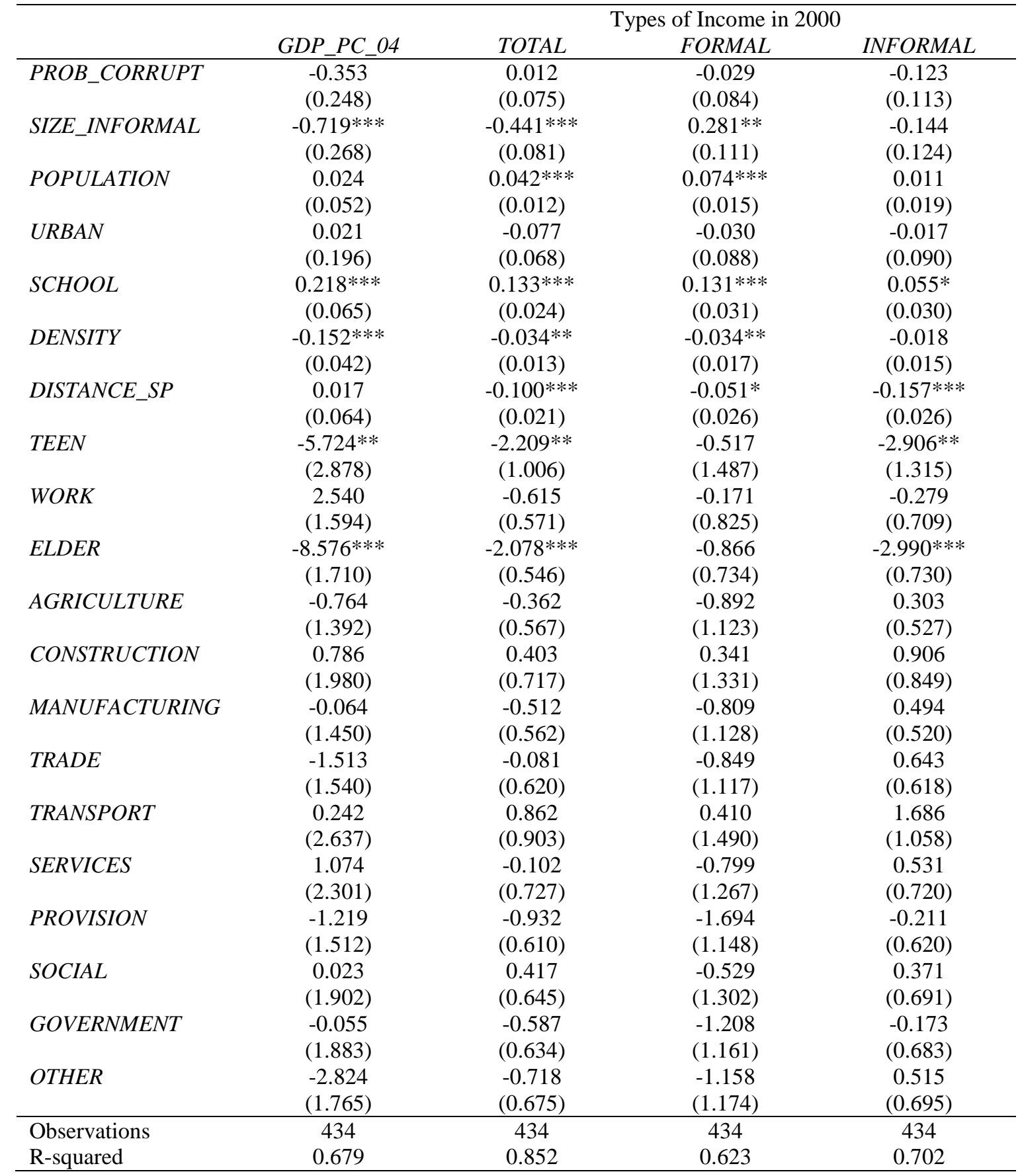

Notes: $* * *$ indicates statistically significant at $1 \%$ level, $* *$ indicates statistically significant at $5 \%$ level, $*$ indicates statistically significant at $10 \%$ level. Standard errors are in parentheses. Constant included in all regressions. 
Table A4: The effect corruption, as measured by the share of audited resources (R\$) found to involve corruption, and the informal economy has on GDP per-capita and income per-capita from different sources with fixed effects.

\begin{tabular}{|c|c|c|c|c|}
\hline \multirow[t]{2}{*}{ 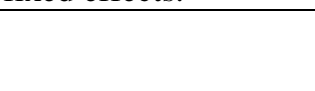 } & \multirow[b]{2}{*}{ GDP_PC_04 } & \multicolumn{3}{|c|}{ Types of Income in 2000} \\
\hline & & TOTAL & FORMAL & INFORMAL \\
\hline \multirow[t]{2}{*}{ PROB_CORRUPT } & -0.475 & 0.015 & -0.072 & -0.062 \\
\hline & $(0.312)$ & $(0.093)$ & $(0.107)$ & $(0.133)$ \\
\hline \multirow{2}{*}{ MISMANAGE } & 0.046 & 0.002 & 0.002 & -0.004 \\
\hline & $(0.050)$ & $(0.010)$ & $(0.013)$ & $(0.012)$ \\
\hline \multirow[t]{2}{*}{ SIZE_INFORMAL } & -0.484 & $-0.448 * * *$ & $0.304^{* *}$ & -0.155 \\
\hline & $(0.294)$ & $(0.105)$ & $(0.131)$ & $(0.161)$ \\
\hline \multirow[t]{2}{*}{ POPULATION } & 0.040 & $0.052 * * *$ & $0.088 * * *$ & 0.014 \\
\hline & $(0.051)$ & $(0.016)$ & $(0.020)$ & $(0.023)$ \\
\hline \multirow[t]{2}{*}{ URBAN } & 0.071 & -0.098 & -0.109 & -0.007 \\
\hline & $(0.234)$ & $(0.084)$ & $(0.104)$ & $(0.115)$ \\
\hline \multirow[t]{2}{*}{ SCHOOL } & $0.225 * * *$ & $0.137 * * *$ & $0.131 * * *$ & 0.054 \\
\hline & $(0.078)$ & $(0.030)$ & $(0.039)$ & $(0.036)$ \\
\hline \multirow[t]{2}{*}{ DENSITY } & $-0.156 * * *$ & $-0.033 * *$ & -0.028 & -0.022 \\
\hline & $(0.048)$ & $(0.016)$ & $(0.019)$ & $(0.020)$ \\
\hline \multirow[t]{2}{*}{ DISTANCE_SP } & 0.028 & $-0.101 * * *$ & -0.051 & $-0.167 * * *$ \\
\hline & $(0.089)$ & $(0.029)$ & $(0.036)$ & $(0.035)$ \\
\hline \multirow[t]{2}{*}{ TEEN } & $-8.184 * *$ & $-3.105^{* *}$ & -1.664 & $-2.936^{*}$ \\
\hline & $(3.498)$ & $(1.283)$ & (1.924) & $(1.703)$ \\
\hline \multirow[t]{2}{*}{ WORK } & 1.519 & -0.851 & -0.337 & -0.275 \\
\hline & $(1.832)$ & $(0.689)$ & $(1.012)$ & $(0.838)$ \\
\hline \multirow[t]{2}{*}{ ELDER } & $-9.137 * * *$ & $-2.480 * * *$ & -1.502 & $-3.079 * * *$ \\
\hline & $(2.168)$ & $(0.691)$ & $(0.949)$ & $(0.910)$ \\
\hline \multirow{2}{*}{ AGRICULTURE } & -2.363 & -0.799 & $-2.760 * *$ & 0.766 \\
\hline & $(2.598)$ & $(0.989)$ & $(1.137)$ & $(0.726)$ \\
\hline \multirow[t]{2}{*}{ CONSTRUCTION } & -2.945 & -0.030 & -2.103 & $2.189^{*}$ \\
\hline & $(3.454)$ & $(1.255)$ & $(1.434)$ & $(1.146)$ \\
\hline \multirow{2}{*}{ MANUFACTURING } & -2.139 & -1.036 & $-2.744 * *$ & 0.892 \\
\hline & $(2.633)$ & $(0.983)$ & $(1.140)$ & $(0.695)$ \\
\hline \multirow[t]{2}{*}{ TRADE } & -2.279 & -0.604 & $-2.617 * *$ & 0.996 \\
\hline & $(2.558)$ & $(1.000)$ & $(1.147)$ & $(0.795)$ \\
\hline \multirow[t]{2}{*}{ TRANSPORT } & -2.981 & 0.269 & -2.064 & 1.958 \\
\hline & $(3.735)$ & $(1.327)$ & $(1.658)$ & (1.333) \\
\hline \multirow[t]{2}{*}{ SERVICES } & 1.789 & -0.712 & $-2.918 * *$ & 1.006 \\
\hline & $(4.340)$ & (1.200) & (1.407) & (1.132) \\
\hline \multirow[t]{2}{*}{ PROVISION } & -2.622 & -1.546 & $-3.706 * * *$ & 0.011 \\
\hline & $(2.633)$ & $(1.029)$ & (1.179) & $(0.841)$ \\
\hline \multirow[t]{2}{*}{ SOCIAL } & -0.998 & -0.045 & $-2.270^{*}$ & 0.688 \\
\hline & $(3.126)$ & (1.110) & $(1.326)$ & $(0.910)$ \\
\hline \multirow[t]{2}{*}{ GOVERNMENT } & -1.201 & -1.128 & $-3.183^{* * *}$ & 0.038 \\
\hline & $(2.881)$ & (1.034) & $(1.214)$ & $(0.834)$ \\
\hline \multirow[t]{2}{*}{ OTHER } & -3.387 & -1.093 & $-2.965^{* *}$ & 0.875 \\
\hline & $(2.865)$ & $(1.086)$ & $(1.242)$ & $(0.874)$ \\
\hline Observations & 331 & 331 & 331 & 331 \\
\hline R-squared & 0.701 & 0.847 & 0.628 & 0.700 \\
\hline
\end{tabular}

Notes: *** indicates statistically significant at $1 \%$ level, ** indicates statistically significant at $5 \%$ level, * indicates statistically significant at $10 \%$ level. Standard errors are in parentheses. Constant included in all regressions. 
Table A5: The effect corruption, as measured by the share of audited items found to involve corruption, and the informal economy has on GDP per-capita and income per-capita from different sources.

\begin{tabular}{|c|c|c|c|c|}
\hline & \multirow[b]{2}{*}{ GDP_PC_04 } & \multicolumn{3}{|c|}{ Types of Income in 2000} \\
\hline & & TOTAL & FORMAL & INFORMAL \\
\hline \multirow[t]{2}{*}{ PROB_CORRUPT_2 } & -0.044 & -0.206 & -0.246 & -0.213 \\
\hline & $(0.477)$ & $(0.177)$ & $(0.226)$ & $(0.239)$ \\
\hline \multirow[t]{2}{*}{ SIZE_INFORMAL } & $-0.925 * * *$ & $-0.399 * * *$ & $0.225^{* *}$ & 0.009 \\
\hline & $(0.205)$ & $(0.078)$ & $(0.108)$ & $(0.104)$ \\
\hline \multirow{2}{*}{ POPULATION } & 0.023 & $0.049 * * *$ & $0.086 * * *$ & 0.017 \\
\hline & $(0.043)$ & $(0.013)$ & $(0.017)$ & $(0.019)$ \\
\hline \multirow[t]{2}{*}{$U R B A N$} & -0.096 & $-0.151 * *$ & -0.114 & -0.090 \\
\hline & $(0.209)$ & $(0.067)$ & $(0.091)$ & $(0.089)$ \\
\hline \multirow[t]{2}{*}{ SCHOOL } & $0.200 * * *$ & $0.199 * * *$ & $0.170 * * *$ & $0.129 * * *$ \\
\hline & $(0.053)$ & $(0.020)$ & $(0.027)$ & $(0.025)$ \\
\hline \multirow[t]{2}{*}{ DENSITY } & $-0.119 * * *$ & $-0.059 * * *$ & $-0.056 * * *$ & $-0.049 * * *$ \\
\hline & $(0.029)$ & $(0.010)$ & $(0.012)$ & $(0.013)$ \\
\hline \multirow{2}{*}{ DISTANCE_SP } & 0.006 & $-0.050 * * *$ & $-0.041 * *$ & $-0.064 * * *$ \\
\hline & $(0.051)$ & $(0.016)$ & $(0.020)$ & $(0.021)$ \\
\hline \multirow[t]{2}{*}{ TEEN } & $-4.954 * *$ & $-4.100 * * *$ & -2.008 & $-5.420 * * *$ \\
\hline & $(2.411)$ & $(0.882)$ & $(1.338)$ & $(1.073)$ \\
\hline \multirow[t]{2}{*}{ WORK } & $4.372 * * *$ & $-1.642 * * *$ & -0.912 & $-1.293 * *$ \\
\hline & $(1.259)$ & $(0.482)$ & $(0.721)$ & $(0.609)$ \\
\hline \multirow[t]{2}{*}{$E L D E R$} & $-6.282 * * *$ & $-4.060 * * *$ & $-2.655 * * *$ & $-5.805 * * *$ \\
\hline & $(1.262)$ & $(0.424)$ & $(0.607)$ & $(0.538)$ \\
\hline \multirow[t]{2}{*}{ AGRICULTURE } & -0.502 & -0.095 & -0.742 & 0.605 \\
\hline & $(1.368)$ & $(0.548)$ & $(1.052)$ & $(0.512)$ \\
\hline \multirow[t]{2}{*}{ CONSTRUCTION } & 0.871 & 0.337 & 0.043 & 0.820 \\
\hline & (1.794) & $(0.672)$ & (1.198) & $(0.831)$ \\
\hline \multirow[t]{2}{*}{ MANUFACTURING } & -0.133 & -0.214 & -0.601 & $0.843^{*}$ \\
\hline & (1.397) & $(0.546)$ & $(1.053)$ & $(0.510)$ \\
\hline \multirow[t]{2}{*}{ TRADE } & -1.736 & 0.231 & -0.554 & $1.137^{*}$ \\
\hline & $(1.585)$ & $(0.588)$ & $(1.031)$ & $(0.623)$ \\
\hline \multirow[t]{2}{*}{ TRANSPORT } & 0.277 & 1.340 & 0.577 & $2.134 *$ \\
\hline & $(2.523)$ & $(0.919)$ & $(1.426)$ & $(1.121)$ \\
\hline \multirow[t]{2}{*}{ SERVICES } & 0.526 & 0.390 & -0.335 & 0.981 \\
\hline & $(2.233)$ & $(0.773)$ & $(1.313)$ & $(0.773)$ \\
\hline \multirow[t]{2}{*}{ PROVISION } & -0.759 & -0.750 & -1.622 & 0.044 \\
\hline & $(1.522)$ & $(0.599)$ & (1.095) & $(0.604)$ \\
\hline \multirow[t]{2}{*}{ SOCIAL } & 0.164 & 0.704 & 0.011 & 0.943 \\
\hline & $(1.771)$ & $(0.678)$ & $(1.261)$ & $(0.713)$ \\
\hline \multirow[t]{2}{*}{ GOVERNMENT } & 0.532 & -0.031 & -0.761 & 0.546 \\
\hline & (1.696) & $(0.596)$ & $(1.121)$ & $(0.626)$ \\
\hline \multirow[t]{2}{*}{ OTHER } & -2.272 & -0.035 & -0.528 & 0.990 \\
\hline & $(1.675)$ & $(0.656)$ & $(1.118)$ & $(0.665)$ \\
\hline Observations & 434 & 434 & 434 & 434 \\
\hline R-squared & 0.630 & 0.806 & 0.505 & 0.623 \\
\hline
\end{tabular}


Table A6: The effect corruption, as measured by the share of audited items found to involve corruption, and the informal economy has on GDP per-capita and income per-capita from different sources.

\begin{tabular}{|c|c|c|c|c|}
\hline & & & of Income il & \\
\hline & GDP_PC_04 & TOTAL & FORMAL & INFORMAL \\
\hline PROB_CORRUPT_2 & -0.189 & -0.262 & -0.348 & -0.007 \\
\hline & $(0.701)$ & $(0.259)$ & $(0.324)$ & $(0.339)$ \\
\hline MISMANAGE & 0.072 & 0.005 & 0.007 & -0.008 \\
\hline & $(0.050)$ & $(0.009)$ & $(0.013)$ & $(0.011)$ \\
\hline SIZE_INFORMAL & $-0.869 * * *$ & $-0.447 * * *$ & 0.165 & 0.016 \\
\hline & $(0.237)$ & (0.099) & $(0.133)$ & $(0.137)$ \\
\hline POPULATION & 0.018 & $0.058 * * *$ & $0.100 * * *$ & 0.023 \\
\hline & $(0.041)$ & $(0.016)$ & $(0.020)$ & $(0.023)$ \\
\hline URBAN & -0.085 & $-0.168 * *$ & $-0.187 *$ & -0.063 \\
\hline & $(0.230)$ & $(0.076)$ & $(0.101)$ & $(0.110)$ \\
\hline SCHOOL & $0.205 * * *$ & $0.189 * * *$ & $0.142 * * *$ & $0.129 * * *$ \\
\hline & $(0.056)$ & $(0.025)$ & $(0.032)$ & $(0.031)$ \\
\hline DENSITY & $-0.131 * * *$ & $-0.060 * * *$ & $-0.056 * * *$ & $-0.052 * * *$ \\
\hline & $(0.033)$ & $(0.011)$ & $(0.014)$ & $(0.015)$ \\
\hline DISTANCE_SP & -0.020 & $-0.056 * * *$ & $-0.051 * *$ & $-0.069 * * *$ \\
\hline & $(0.061)$ & $(0.019)$ & $(0.023)$ & $(0.025)$ \\
\hline TEEN & $-5.062^{*}$ & $-4.604 * * *$ & -2.276 & $-5.640 * * *$ \\
\hline & $(2.645)$ & $(1.052)$ & (1.623) & (1.309) \\
\hline WORK & $4.451 * * *$ & $-1.651 * * *$ & -0.528 & $-1.382 *$ \\
\hline & (1.391) & $(0.557)$ & $(0.859)$ & $(0.729)$ \\
\hline ELDER & $-5.984 * * *$ & $-4.270 * * *$ & $-2.938 * * *$ & $-5.888 * * *$ \\
\hline & $(1.342)$ & $(0.536)$ & $(0.771)$ & $(0.678)$ \\
\hline AGRICULTURE & -1.537 & -0.691 & $-2.612 * *$ & 1.005 \\
\hline & $(2.015)$ & $(0.913)$ & $(1.045)$ & $(0.723)$ \\
\hline CONSTRUCTION & -1.365 & -0.366 & $-2.174 *$ & 1.759 \\
\hline & (2.759) & (1.154) & (1.303) & (1.130) \\
\hline MANUFACTURING & -1.329 & -0.890 & $-2.484 * *$ & $1.167^{*}$ \\
\hline & $(2.050)$ & (0.903) & $(1.045)$ & $(0.704)$ \\
\hline TRADE & -1.876 & -0.335 & $-2.189 * *$ & $1.510 *$ \\
\hline & $(2.130)$ & $(0.917)$ & $(1.051)$ & $(0.823)$ \\
\hline TRANSPORT & -2.273 & 0.808 & -1.685 & $2.854^{* *}$ \\
\hline & (3.164) & (1.295) & (1.512) & (1.414) \\
\hline SERVICES & 1.255 & -0.289 & $-2.490^{*}$ & 1.409 \\
\hline & $(3.850)$ & $(1.224)$ & $(1.449)$ & $(1.208)$ \\
\hline PROVISION & -1.961 & -1.441 & $-3.565 * * *$ & 0.215 \\
\hline & (2.147) & $(0.958)$ & $(1.115)$ & $(0.839)$ \\
\hline SOCIAL & -0.540 & 0.035 & -1.766 & 1.046 \\
\hline & $(2.478)$ & (1.076) & (1.298) & $(0.951)$ \\
\hline GOVERNMENT & -0.694 & -0.527 & $-2.734 * *$ & 1.038 \\
\hline & (2.266) & $(0.948)$ & (1.134) & $(0.798)$ \\
\hline OTHER & -2.656 & -0.550 & $-2.305^{*}$ & 1.356 \\
\hline & $(2.353)$ & $(1.035)$ & $(1.190)$ & $(0.856)$ \\
\hline Observations & 331 & 331 & 331 & 331 \\
\hline R-squared & 0.653 & 0.799 & 0.506 & 0.612 \\
\hline
\end{tabular}

Notes: *** indicates statistically significant at $1 \%$ level, ** indicates statistically significant at $5 \%$ level, $*$ indicates statistically significant at $10 \%$ level. Standard errors are in parentheses. Constant included in all regressions. 
Table A7: The effect corruption, as measured by the share of audited items found to involve corruption, and the informal economy has on GDP per-capita and income per-capita from different sources with fixed effects.

\begin{tabular}{|c|c|c|c|c|}
\hline & \multirow[b]{2}{*}{ GDP_PC_04 } & \multicolumn{3}{|c|}{ Types of Income in 2000} \\
\hline & & TOTAL & FORMAL & INFORMAL \\
\hline \multirow[t]{2}{*}{$\overline{P R O B} \_C O R R U P T \_2$} & -0.043 & -0.104 & -0.226 & -0.022 \\
\hline & $(0.497)$ & $(0.204)$ & $(0.237)$ & $(0.264)$ \\
\hline \multirow[t]{2}{*}{ SIZE_INFORMAL } & $-0.706^{* * *}$ & $-0.444 * * *$ & $0.276^{* *}$ & -0.140 \\
\hline & $(0.268)$ & $(0.080)$ & $(0.111)$ & $(0.124)$ \\
\hline \multirow[t]{2}{*}{ POPULATION } & 0.027 & $0.042 * * *$ & $0.074 * * *$ & 0.012 \\
\hline & $(0.052)$ & $(0.012)$ & $(0.015)$ & $(0.019)$ \\
\hline \multirow[t]{2}{*}{$U R B A N$} & 0.010 & -0.074 & -0.025 & -0.021 \\
\hline & $(0.195)$ & $(0.068)$ & $(0.088)$ & $(0.092)$ \\
\hline \multirow[t]{2}{*}{ SCHOOL } & $0.215 * * *$ & $0.131 * * *$ & $0.128 * * *$ & $0.054 *$ \\
\hline & $(0.066)$ & $(0.024)$ & $(0.032)$ & $(0.030)$ \\
\hline \multirow[t]{2}{*}{ DENSITY } & $-0.152 * * *$ & $-0.034 * *$ & $-0.033^{*}$ & -0.019 \\
\hline & $(0.042)$ & $(0.013)$ & $(0.017)$ & $(0.015)$ \\
\hline \multirow[t]{2}{*}{ DISTANCE_SP } & 0.007 & $-0.100 * * *$ & $-0.052 * *$ & $-0.161 * * *$ \\
\hline & $(0.065)$ & $(0.021)$ & $(0.026)$ & $(0.027)$ \\
\hline \multirow[t]{2}{*}{ TEEN } & $-5.593^{*}$ & $-2.249 * *$ & -0.582 & $-2.863 * *$ \\
\hline & $(2.890)$ & $(0.995)$ & $(1.491)$ & $(1.285)$ \\
\hline \multirow[t]{2}{*}{ WORK } & $2.652^{*}$ & -0.650 & -0.228 & -0.242 \\
\hline & $(1.582)$ & $(0.561)$ & $(0.826)$ & $(0.683)$ \\
\hline \multirow[t]{2}{*}{ ELDER } & $-8.730 * * *$ & $-2.062 * * *$ & -0.855 & $-3.043 * * *$ \\
\hline & $(1.722)$ & $(0.546)$ & $(0.727)$ & $(0.724)$ \\
\hline \multirow[t]{2}{*}{ AGRICULTURE } & -0.871 & -0.345 & -0.873 & 0.266 \\
\hline & $(1.386)$ & $(0.578)$ & (1.136) & $(0.523)$ \\
\hline \multirow[t]{2}{*}{ CONSTRUCTION } & 0.344 & 0.419 & 0.308 & 0.752 \\
\hline & $(1.884)$ & $(0.712)$ & $(1.335)$ & $(0.907)$ \\
\hline \multirow[t]{2}{*}{ MANUFACTURING } & -0.173 & -0.500 & -0.799 & 0.457 \\
\hline & $(1.441)$ & $(0.572)$ & $(1.141)$ & $(0.514)$ \\
\hline \multirow{2}{*}{$T R A D E$} & -1.497 & -0.069 & -0.823 & 0.650 \\
\hline & $(1.546)$ & $(0.632)$ & $(1.132)$ & $(0.621)$ \\
\hline \multirow[t]{2}{*}{ TRANSPORT } & 0.091 & 0.907 & 0.484 & 1.636 \\
\hline & $(2.663)$ & $(0.900)$ & (1.499) & $(1.029)$ \\
\hline \multirow[t]{2}{*}{ SERVICES } & 1.030 & -0.089 & -0.778 & 0.517 \\
\hline & $(2.309)$ & $(0.742)$ & $(1.289)$ & $(0.720)$ \\
\hline \multirow[t]{2}{*}{ PROVISION } & -1.324 & -0.909 & -1.662 & -0.247 \\
\hline & $(1.507)$ & $(0.618)$ & $(1.161)$ & $(0.607)$ \\
\hline \multirow[t]{2}{*}{ SOCIAL } & -0.047 & 0.445 & -0.480 & 0.348 \\
\hline & $(1.901)$ & $(0.656)$ & $(1.316)$ & $(0.681)$ \\
\hline \multirow[t]{2}{*}{ GOVERNMENT } & -0.064 & -0.578 & -1.192 & -0.176 \\
\hline & $(1.901)$ & $(0.645)$ & (1.174) & $(0.686)$ \\
\hline \multirow[t]{2}{*}{ OTHER } & $-2.947^{*}$ & -0.703 & -1.145 & 0.473 \\
\hline & $(1.760)$ & $(0.684)$ & $(1.185)$ & $(0.686)$ \\
\hline Observations & 434 & 434 & 434 & 434 \\
\hline R-squared & 0.677 & 0.852 & 0.624 & 0.700 \\
\hline
\end{tabular}

Notes: $* * *$ indicates statistically significant at $1 \%$ level, $* *$ indicates statistically significant at $5 \%$ level, * indicates statistically significant at $10 \%$ level. Standard errors are in parentheses. Constant included in all regressions. 
Table A8: The effect corruption, as measured by the share of audited items found to involve corruption, and the informal economy has on GDP per-capita and income per-capita from different sources with fixed effects.

\begin{tabular}{|c|c|c|c|c|}
\hline & \multirow[b]{2}{*}{ GDP_PC_04 } & \multicolumn{3}{|c|}{ Types of Income in 2000} \\
\hline & & TOTAL & FORMAL & INFORMAL \\
\hline \multirow{2}{*}{ PROB_CORRUPT_2 } & 0.299 & -0.023 & -0.240 & 0.217 \\
\hline & $(0.729)$ & $(0.260)$ & $(0.333)$ & $(0.326)$ \\
\hline \multirow[t]{2}{*}{ MISMANAGE } & 0.036 & 0.003 & 0.005 & -0.008 \\
\hline & $(0.054)$ & $(0.009)$ & $(0.014)$ & $(0.012)$ \\
\hline \multirow[t]{2}{*}{ SIZE_INFORMAL } & -0.449 & $-0.449 * * *$ & $0.296^{* *}$ & -0.141 \\
\hline & $(0.290)$ & $(0.106)$ & $(0.133)$ & $(0.163)$ \\
\hline \multirow[t]{2}{*}{ POPULATION } & 0.046 & $0.051 * * *$ & $0.089 * * *$ & 0.015 \\
\hline & $(0.052)$ & $(0.016)$ & $(0.020)$ & $(0.023)$ \\
\hline \multirow[t]{2}{*}{$U R B A N$} & 0.029 & -0.097 & -0.110 & -0.015 \\
\hline & $(0.230)$ & $(0.084)$ & $(0.103)$ & $(0.117)$ \\
\hline \multirow[t]{2}{*}{ SCHOOL } & $0.226^{* * *}$ & $0.136^{* * * *}$ & $0.130 * * *$ & 0.055 \\
\hline & $(0.079)$ & $(0.031)$ & $(0.039)$ & $(0.037)$ \\
\hline \multirow[t]{2}{*}{ DENSITY } & $-0.161 * * *$ & $-0.033 * *$ & -0.027 & -0.023 \\
\hline & $(0.049)$ & $(0.016)$ & $(0.019)$ & $(0.019)$ \\
\hline \multirow[t]{2}{*}{ DISTANCE_SP } & 0.010 & $-0.100 * * *$ & -0.051 & $-0.171 * * *$ \\
\hline & $(0.089)$ & $(0.029)$ & $(0.035)$ & $(0.035)$ \\
\hline \multirow{2}{*}{ TEEN } & $-7.801 * *$ & $-3.123 * *$ & -1.747 & $-2.798 *$ \\
\hline & $(3.551)$ & $(1.260)$ & $(1.923)$ & $(1.653)$ \\
\hline \multirow[t]{2}{*}{ WORK } & 1.863 & -0.866 & -0.376 & -0.173 \\
\hline & $(1.826)$ & $(0.679)$ & (1.014) & $(0.808)$ \\
\hline \multirow[t]{2}{*}{ ELDER } & $-9.192 * * *$ & $-2.479 * * *$ & -1.527 & $-3.076 * * *$ \\
\hline & $(2.165)$ & $(0.694)$ & $(0.943)$ & $(0.905)$ \\
\hline \multirow[t]{2}{*}{ AGRICULTURE } & -2.563 & -0.792 & $-2.760 * *$ & 0.721 \\
\hline & $(2.500)$ & $(0.992)$ & $(1.162)$ & $(0.701)$ \\
\hline \multirow[t]{2}{*}{ CONSTRUCTION } & -3.071 & -0.027 & -2.138 & $2.183^{*}$ \\
\hline & $(3.360)$ & $(1.258)$ & $(1.455)$ & $(1.131)$ \\
\hline \multirow[t]{2}{*}{ MANUFACTURING } & -2.299 & -1.031 & $-2.762 * *$ & 0.867 \\
\hline & $(2.537)$ & $(0.985)$ & (1.164) & $(0.669)$ \\
\hline \multirow[t]{2}{*}{ TRADE } & -2.294 & -0.603 & $-2.620 * *$ & 0.995 \\
\hline & $(2.487)$ & (1.004) & (1.170) & $(0.780)$ \\
\hline \multirow[t]{2}{*}{ TRANSPORT } & -3.432 & 0.288 & -2.035 & 1.838 \\
\hline & $(3.688)$ & (1.318) & $(1.673)$ & $(1.296)$ \\
\hline \multirow[t]{2}{*}{ SERVICES } & 1.571 & -0.705 & $-2.956 * *$ & 0.982 \\
\hline & $(4.293)$ & (1.204) & $(1.421)$ & (1.119) \\
\hline \multirow[t]{2}{*}{ PROVISION } & -2.938 & -1.533 & $-3.699 * * *$ & -0.064 \\
\hline & (2.543) & $(1.030)$ & (1.204) & $(0.812)$ \\
\hline \multirow[t]{2}{*}{ SOCIAL } & -1.166 & -0.037 & $-2.242 *$ & 0.633 \\
\hline & (3.036) & (1.113) & $(1.354)$ & $(0.882)$ \\
\hline \multirow[t]{2}{*}{ GOVERNMENT } & -1.453 & -1.118 & $-3.196 * *$ & -0.011 \\
\hline & $(2.808)$ & $(1.036)$ & $(1.233)$ & $(0.824)$ \\
\hline \multirow[t]{2}{*}{ OTHER } & -3.542 & -1.088 & $-2.979 * *$ & 0.849 \\
\hline & $(2.777)$ & $(1.090)$ & $(1.264)$ & $(0.848)$ \\
\hline Observations & 331 & 331 & 331 & 331 \\
\hline R-squared & 0.698 & 0.847 & 0.628 & 0.701 \\
\hline
\end{tabular}

Notes: *** indicates statistically significant at $1 \%$ level, ** indicates statistically significant at $5 \%$ level, * indicates statistically significant at $10 \%$ level. Standard errors are in parentheses. Constant included in all regressions. 
Table A9: The effect corruption, as measured by the share of audited resources (R\$) found to involve corruption, and the informal economy has on GDP per-capita and income per-capita from different sources.

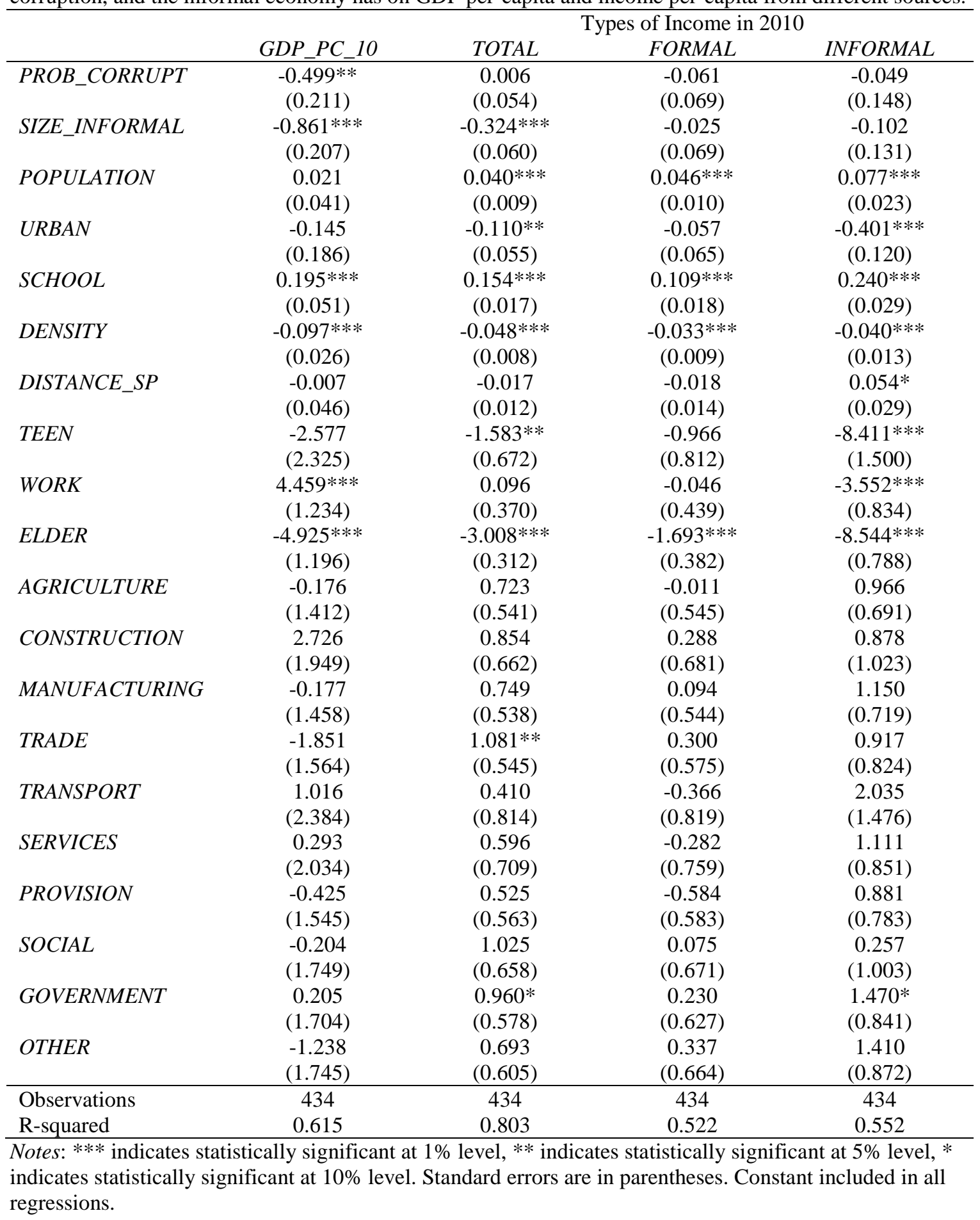


Table A10: The effect corruption, as measured by the share of audited resources (R\$) found to involve corruption, and the informal economy has on GDP per-capita and income per-capita from different sources.

\begin{tabular}{|c|c|c|c|c|}
\hline & \multirow[b]{2}{*}{$G D P \_P C \_10$} & \multicolumn{3}{|c|}{ Types of Income in 2010} \\
\hline & & TOTAL & FORMAL & INFORMAL \\
\hline \multirow[t]{2}{*}{ PROB_CORRUPT } & $-0.421^{*}$ & -0.017 & -0.100 & -0.118 \\
\hline & $(0.235)$ & $(0.063)$ & $(0.080)$ & $(0.169)$ \\
\hline \multirow[t]{2}{*}{ MISMANAGE } & 0.055 & -0.001 & $0.013 *$ & $-0.043 * * *$ \\
\hline & $(0.035)$ & $(0.006)$ & $(0.007)$ & $(0.014)$ \\
\hline \multirow{2}{*}{ SIZE_INFORMAL } & $-0.839 * * *$ & $-0.379 * * *$ & -0.089 & -0.003 \\
\hline & $(0.235)$ & $(0.071)$ & $(0.083)$ & $(0.147)$ \\
\hline \multirow[t]{2}{*}{ POPULATION } & 0.011 & $0.049 * * *$ & $0.052 * * *$ & $0.083 * * *$ \\
\hline & $(0.039)$ & $(0.011)$ & $(0.012)$ & $(0.027)$ \\
\hline \multirow[t]{2}{*}{ URBAN } & -0.140 & $-0.134 * *$ & -0.048 & $-0.423 * * *$ \\
\hline & $(0.202)$ & $(0.063)$ & $(0.076)$ & $(0.139)$ \\
\hline \multirow[t]{2}{*}{ SCHOOL } & $0.205^{* * *}$ & $0.137 * * *$ & $0.099 * * *$ & $0.229 * * *$ \\
\hline & $(0.052)$ & $(0.019)$ & $(0.022)$ & $(0.033)$ \\
\hline \multirow[t]{2}{*}{ DENSITY } & $-0.100 * * *$ & $-0.049 * * *$ & $-0.035 * * *$ & $-0.030 * *$ \\
\hline & $(0.027)$ & $(0.009)$ & $(0.010)$ & $(0.014)$ \\
\hline \multirow[t]{2}{*}{ DISTANCE_SP } & -0.024 & -0.020 & -0.012 & 0.047 \\
\hline & $(0.054)$ & $(0.015)$ & $(0.016)$ & $(0.035)$ \\
\hline \multirow[t]{2}{*}{ TEEN } & -2.257 & $-1.974 * * *$ & -0.905 & $-8.294 * * *$ \\
\hline & $(2.539)$ & $(0.760)$ & $(0.965)$ & $(1.629)$ \\
\hline \multirow[t]{2}{*}{ WORK } & $4.683 * * *$ & 0.192 & 0.244 & $-3.476 * * *$ \\
\hline & $(1.362)$ & $(0.411)$ & $(0.505)$ & $(0.933)$ \\
\hline \multirow[t]{2}{*}{$E L D E R$} & $-4.490 * * *$ & $-2.992 * * *$ & $-1.735 * * *$ & $-8.243 * * *$ \\
\hline & $(1.263)$ & $(0.393)$ & $(0.502)$ & $(0.912)$ \\
\hline \multirow[t]{2}{*}{ AGRICULTURE } & -1.503 & 0.081 & -0.316 & -0.218 \\
\hline & $(2.064)$ & $(0.824)$ & (1.006) & $(1.112)$ \\
\hline \multirow[t]{2}{*}{ CONSTRUCTION } & -0.414 & 0.062 & -0.082 & -1.160 \\
\hline & $(2.834)$ & $(1.061)$ & $(1.263)$ & $(1.485)$ \\
\hline \multirow[t]{2}{*}{ MANUFACTURING } & -1.872 & 0.107 & -0.207 & -0.071 \\
\hline & $(2.102)$ & $(0.811)$ & $(0.999)$ & $(1.127)$ \\
\hline \multirow[t]{2}{*}{ TRADE } & -2.480 & 0.473 & 0.002 & -0.285 \\
\hline & $(2.113)$ & $(0.799)$ & $(0.976)$ & (1.188) \\
\hline \multirow[t]{2}{*}{ TRANSPORT } & -1.767 & -0.521 & -1.220 & 1.584 \\
\hline & $(3.011)$ & $(1.110)$ & $(1.279)$ & $(1.930)$ \\
\hline \multirow[t]{2}{*}{ SERVICES } & 0.596 & -0.163 & -0.604 & 0.071 \\
\hline & $(3.499)$ & $(1.055)$ & $(1.251)$ & $(1.347)$ \\
\hline \multirow[t]{2}{*}{ PROVISION } & -1.745 & -0.169 & -0.894 & -0.331 \\
\hline & $(2.152)$ & $(0.827)$ & $(1.035)$ & $(1.167)$ \\
\hline \multirow[t]{2}{*}{ SOCIAL } & -1.035 & 0.486 & -0.267 & -1.272 \\
\hline & $(2.412)$ & $(0.958)$ & (1.180) & (1.404) \\
\hline \multirow[t]{2}{*}{ GOVERNMENT } & -1.334 & 0.474 & -0.010 & 0.639 \\
\hline & $(2.243)$ & $(0.867)$ & (1.080) & (1.269) \\
\hline \multirow[t]{2}{*}{ OTHER } & -1.674 & 0.056 & -0.154 & 0.725 \\
\hline & $(2.414)$ & $(0.898)$ & $(1.087)$ & $(1.278)$ \\
\hline Observations & 331 & 331 & 331 & 331 \\
\hline R-squared & 0.656 & 0.800 & 0.512 & 0.555 \\
\hline
\end{tabular}

Notes: *** indicates statistically significant at $1 \%$ level, ** indicates statistically significant at $5 \%$ level, * indicates statistically significant at $10 \%$ level. Standard errors are in parentheses. Constant included in all regressions. 
Table A11: The effect corruption, as measured by the share of audited resources (R $\$$ ) found to involve corruption, and the informal economy has on GDP per-capita and income per-capita from different sources with fixed effects.

\begin{tabular}{|c|c|c|c|c|}
\hline & \multirow[b]{2}{*}{$G D P \_P C \_10$} & \multicolumn{3}{|c|}{ Types of Income in 2010} \\
\hline & & TOTAL & FORMAL & INFORMAL \\
\hline \multirow[t]{2}{*}{ PROB_CORRUPT } & -0.311 & -0.003 & -0.085 & 0.131 \\
\hline & $(0.214)$ & $(0.051)$ & $(0.065)$ & $(0.103)$ \\
\hline \multirow[t]{2}{*}{ SIZE_INFORMAL } & $-0.638 * *$ & $-0.263 * * *$ & 0.096 & $-0.256 * *$ \\
\hline & $(0.265)$ & $(0.065)$ & $(0.074)$ & $(0.126)$ \\
\hline \multirow[t]{2}{*}{ POPULATION } & 0.016 & $0.047 * * *$ & $0.049 * * *$ & $0.056 * * *$ \\
\hline & $(0.050)$ & $(0.009)$ & $(0.011)$ & $(0.016)$ \\
\hline \multirow[t]{2}{*}{$U R B A N$} & -0.075 & -0.088 & -0.034 & $-0.220 * *$ \\
\hline & $(0.177)$ & $(0.056)$ & $(0.069)$ & $(0.093)$ \\
\hline \multirow[t]{2}{*}{ SCHOOL } & $0.203 * * *$ & $0.119 * * *$ & $0.097 * * *$ & $0.051 *$ \\
\hline & $(0.064)$ & $(0.019)$ & $(0.021)$ & $(0.026)$ \\
\hline \multirow[t]{2}{*}{ DENSITY } & $-0.117 * * *$ & $-0.026 * *$ & -0.018 & 0.013 \\
\hline & $(0.035)$ & $(0.011)$ & $(0.011)$ & $(0.013)$ \\
\hline \multirow[t]{2}{*}{ DISTANCE_SP } & -0.027 & -0.005 & 0.004 & $-0.084 * * *$ \\
\hline & $(0.062)$ & $(0.017)$ & $(0.020)$ & $(0.025)$ \\
\hline \multirow[t]{2}{*}{ TEEN } & -3.383 & $-1.260 *$ & -1.104 & $-2.617 *$ \\
\hline & $(2.856)$ & $(0.734)$ & $(0.854)$ & $(1.380)$ \\
\hline \multirow[t]{2}{*}{ WORK } & $2.962 *$ & 0.218 & 0.018 & 0.717 \\
\hline & $(1.546)$ & $(0.405)$ & $(0.481)$ & $(0.720)$ \\
\hline \multirow[t]{2}{*}{ ELDER } & $-6.956 * * *$ & $-1.719 * * *$ & $-0.899 *$ & $-2.633 * * *$ \\
\hline & $(1.531)$ & $(0.430)$ & $(0.489)$ & $(0.749)$ \\
\hline \multirow[t]{2}{*}{ AGRICULTURE } & -0.486 & 0.410 & -0.270 & 0.448 \\
\hline & $(1.452)$ & $(0.585)$ & $(0.616)$ & $(0.631)$ \\
\hline \multirow[t]{2}{*}{ CONSTRUCTION } & 1.856 & 0.890 & 0.388 & 0.608 \\
\hline & $(2.031)$ & $(0.708)$ & $(0.739)$ & $(0.807)$ \\
\hline \multirow[t]{2}{*}{ MANUFACTURING } & 0.004 & 0.475 & -0.153 & 0.632 \\
\hline & $(1.522)$ & $(0.585)$ & $(0.615)$ & $(0.639)$ \\
\hline \multirow[t]{2}{*}{ TRADE } & -1.279 & 0.659 & -0.199 & 0.229 \\
\hline & $(1.565)$ & $(0.596)$ & $(0.641)$ & $(0.660)$ \\
\hline \multirow[t]{2}{*}{ TRANSPORT } & 0.401 & -0.184 & -0.862 & 1.011 \\
\hline & $(2.563)$ & $(0.804)$ & $(0.855)$ & $(1.183)$ \\
\hline \multirow[t]{2}{*}{ SERVICES } & 0.735 & 0.284 & -0.603 & 0.464 \\
\hline & $(2.093)$ & $(0.680)$ & $(0.708)$ & $(0.716)$ \\
\hline \multirow[t]{2}{*}{ PROVISION } & -0.887 & 0.244 & -0.777 & 0.848 \\
\hline & $(1.562)$ & $(0.604)$ & $(0.648)$ & $(0.692)$ \\
\hline \multirow[t]{2}{*}{ SOCIAL } & -0.690 & 0.975 & -0.140 & -0.281 \\
\hline & $(1.865)$ & $(0.675)$ & $(0.704)$ & $(0.868)$ \\
\hline \multirow[t]{2}{*}{ GOVERNMENT } & -0.410 & 0.482 & -0.284 & -0.073 \\
\hline & $(1.906)$ & $(0.622)$ & $(0.700)$ & $(0.724)$ \\
\hline \multirow[t]{2}{*}{ OTHER } & -1.726 & 0.229 & -0.167 & 0.411 \\
\hline & $(1.862)$ & $(0.663)$ & $(0.729)$ & $(0.727)$ \\
\hline Observations & 434 & 434 & 434 & 434 \\
\hline R-squared & 0.665 & 0.854 & 0.633 & 0.801 \\
\hline
\end{tabular}


Table A12: The effect corruption, as measured by the share of audited resources (R $\$$ ) found to involve corruption, and the informal economy has on GDP per-capita and income per-capita from different sources with fixed effects.

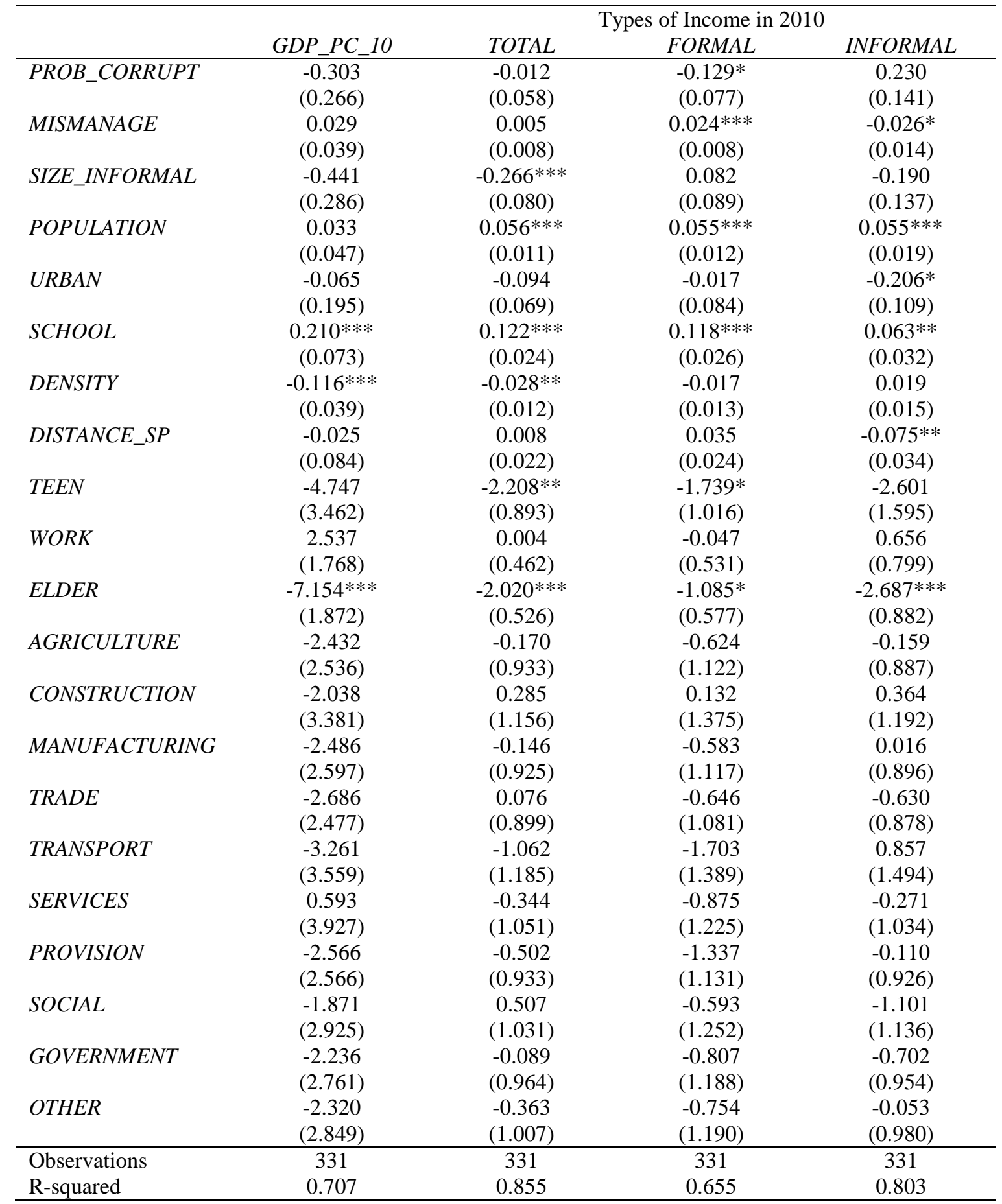

Notes: *** indicates statistically significant at $1 \%$ level, ** indicates statistically significant at $5 \%$ level, * indicates statistically significant at $10 \%$ level. Standard errors are in parentheses. Constant included in all regressions. 
Table A13: The effect corruption, as measured by the share of audited items found to involve corruption, and the informal economy has on GDP per-capita and income per-capita from different sources.

\begin{tabular}{|c|c|c|c|c|}
\hline & \multirow[b]{2}{*}{$G D P \_P C_{-} 10$} & \multicolumn{3}{|c|}{ Types of Income in 2010} \\
\hline & & TOTAL & FORMAL & INFORMAL \\
\hline \multirow{2}{*}{$P R O B \_C O R R U P T \_2$} & -0.167 & 0.124 & 0.144 & -0.191 \\
\hline & $(0.404)$ & $(0.121)$ & $(0.128)$ & $(0.264)$ \\
\hline \multirow[t]{2}{*}{ SIZE_INFORMAL } & $-0.837 * * *$ & $-0.323 * * *$ & -0.020 & -0.101 \\
\hline & $(0.204)$ & $(0.060)$ & $(0.069)$ & $(0.131)$ \\
\hline \multirow{2}{*}{ POPULATION } & 0.027 & $0.041 * * *$ & $0.048 * * *$ & $0.077 * * *$ \\
\hline & $(0.042)$ & $(0.009)$ & $(0.010)$ & $(0.023)$ \\
\hline \multirow[t]{2}{*}{$U R B A N$} & -0.173 & $-0.113 * *$ & -0.064 & $-0.400 * * *$ \\
\hline & $(0.186)$ & $(0.055)$ & $(0.064)$ & $(0.120)$ \\
\hline \multirow{2}{*}{ SCHOOL } & $0.198 * * *$ & $0.156 * * *$ & $0.112 * * *$ & $0.237 * * *$ \\
\hline & $(0.052)$ & $(0.017)$ & $(0.019)$ & $(0.030)$ \\
\hline \multirow[t]{2}{*}{ DENSITY } & $-0.098 * * *$ & $-0.048 * * *$ & $-0.034 * * *$ & $-0.040 * * *$ \\
\hline & $(0.026)$ & $(0.008)$ & $(0.008)$ & $(0.013)$ \\
\hline \multirow[t]{2}{*}{ DISTANCE_SP } & -0.012 & -0.015 & -0.017 & $0.051 *$ \\
\hline & $(0.047)$ & $(0.012)$ & $(0.014)$ & $(0.029)$ \\
\hline \multirow[t]{2}{*}{ TEEN } & -2.930 & $-1.658 * *$ & -1.117 & $-8.331 * * *$ \\
\hline & $(2.371)$ & $(0.668)$ & $(0.817)$ & $(1.518)$ \\
\hline \multirow[t]{2}{*}{ WORK } & $4.393 * * *$ & 0.097 & -0.054 & $-3.558 * * *$ \\
\hline & $(1.242)$ & $(0.369)$ & $(0.440)$ & $(0.832)$ \\
\hline \multirow[t]{2}{*}{ ELDER } & $-5.136 * * *$ & $-3.039 * * *$ & $-1.764 * * *$ & $-8.517 * * *$ \\
\hline & $(1.208)$ & $(0.312)$ & $(0.378)$ & $(0.795)$ \\
\hline \multirow[t]{2}{*}{ AGRICULTURE } & -0.289 & 0.729 & -0.020 & 0.949 \\
\hline & $(1.447)$ & $(0.529)$ & $(0.526)$ & $(0.700)$ \\
\hline \multirow[t]{2}{*}{ CONSTRUCTION } & 2.154 & 0.872 & 0.232 & 0.807 \\
\hline & (1.895) & $(0.635)$ & $(0.647)$ & $(1.031)$ \\
\hline \multirow[t]{2}{*}{ MANUFACTURING } & -0.285 & 0.758 & 0.091 & 1.129 \\
\hline & $(1.490)$ & $(0.527)$ & $(0.525)$ & $(0.731)$ \\
\hline \multirow[t]{2}{*}{ TRADE } & -1.835 & $1.073^{* *}$ & 0.291 & 0.930 \\
\hline & (1.597) & $(0.536)$ & $(0.559)$ & $(0.832)$ \\
\hline \multirow[t]{2}{*}{ TRANSPORT } & 0.905 & 0.381 & -0.420 & 2.068 \\
\hline & $(2.425)$ & $(0.809)$ & $(0.809)$ & $(1.479)$ \\
\hline \multirow[t]{2}{*}{ SERVICES } & 0.252 & 0.585 & -0.302 & 1.123 \\
\hline & $(2.068)$ & $(0.694)$ & $(0.737)$ & $(0.863)$ \\
\hline \multirow[t]{2}{*}{ PROVISION } & -0.502 & 0.532 & -0.586 & 0.865 \\
\hline & $(1.582)$ & $(0.552)$ & $(0.566)$ & $(0.791)$ \\
\hline \multirow[t]{2}{*}{ SOCIAL } & -0.252 & 1.022 & 0.063 & 0.258 \\
\hline & (1.792) & $(0.648)$ & $(0.655)$ & (1.013) \\
\hline \multirow[t]{2}{*}{ GOVERNMENT } & 0.208 & $0.984 *$ & 0.264 & $1.435^{*}$ \\
\hline & $(1.736)$ & $(0.569)$ & $(0.611)$ & $(0.850)$ \\
\hline \multirow[t]{2}{*}{ OTHER } & -1.349 & 0.690 & 0.318 & 1.405 \\
\hline & $(1.779)$ & $(0.594)$ & $(0.644)$ & $(0.880)$ \\
\hline Observations & 434 & 434 & 434 & 434 \\
\hline R-squared & 0.610 & 0.803 & 0.522 & 0.552 \\
\hline
\end{tabular}


Table A14: The effect corruption, as measured by the share of audited items found to involve corruption, and the informal economy has on GDP per-capita and income per-capita from different sources.

\begin{tabular}{|c|c|c|c|c|}
\hline & \multirow[b]{2}{*}{$G D P \_P C_{-} 10$} & \multicolumn{3}{|c|}{ Types of Income in 2010} \\
\hline & & TOTAL & FORMAL & INFORMAL \\
\hline \multirow{2}{*}{ PROB_CORRUPT_2 } & -0.102 & 0.175 & 0.133 & 0.125 \\
\hline & $(0.617)$ & $(0.182)$ & $(0.202)$ & $(0.335)$ \\
\hline \multirow[t]{2}{*}{ MISMANAGE } & 0.053 & -0.004 & 0.010 & $-0.046^{* * *}$ \\
\hline & $(0.041)$ & $(0.007)$ & $(0.008)$ & $(0.015)$ \\
\hline \multirow[t]{2}{*}{ SIZE_INFORMAL } & $-0.817 * * *$ & $-0.372 * * *$ & -0.079 & 0.008 \\
\hline & $(0.232)$ & $(0.072)$ & $(0.084)$ & $(0.149)$ \\
\hline \multirow[t]{2}{*}{ POPULATION } & 0.017 & $0.050 * * *$ & $0.054 * * *$ & $0.086^{* * *}$ \\
\hline & $(0.039)$ & $(0.011)$ & $(0.012)$ & $(0.027)$ \\
\hline \multirow[t]{2}{*}{ URBAN } & -0.177 & $-0.140 * *$ & -0.061 & $-0.438 * * *$ \\
\hline & $(0.198)$ & $(0.062)$ & $(0.075)$ & $(0.138)$ \\
\hline \multirow[t]{2}{*}{ SCHOOL } & $0.211 * * *$ & $0.140 * * *$ & $0.103 * * *$ & $0.233 * * *$ \\
\hline & $(0.054)$ & $(0.020)$ & $(0.023)$ & $(0.033)$ \\
\hline \multirow[t]{2}{*}{ DENSITY } & $-0.102 * * *$ & $-0.049 * * *$ & $-0.035^{* * *}$ & $-0.031 * *$ \\
\hline & $(0.027)$ & $(0.009)$ & $(0.010)$ & $(0.014)$ \\
\hline \multirow[t]{2}{*}{ DISTANCE_SP } & -0.024 & -0.019 & -0.010 & 0.049 \\
\hline & $(0.055)$ & $(0.015)$ & $(0.016)$ & $(0.036)$ \\
\hline \multirow[t]{2}{*}{ TEEN } & -2.564 & $-2.087 * * *$ & -1.067 & $-8.467 * * *$ \\
\hline & $(2.556)$ & $(0.770)$ & (0.978) & $(1.669)$ \\
\hline \multirow[t]{2}{*}{ WORK } & $4.647 * * *$ & 0.187 & 0.232 & $-3.490 * * *$ \\
\hline & $(1.373)$ & $(0.411)$ & $(0.510)$ & $(0.937)$ \\
\hline \multirow[t]{2}{*}{ ELDER } & $-4.604 * * *$ & $-3.002 * * *$ & $-1.767 * * *$ & $-8.280 * * *$ \\
\hline & $(1.261)$ & $(0.394)$ & $(0.500)$ & $(0.919)$ \\
\hline \multirow[t]{2}{*}{ AGRICULTURE } & -1.617 & 0.074 & -0.345 & -0.252 \\
\hline & $(2.052)$ & $(0.791)$ & (0.969) & (1.080) \\
\hline \multirow[t]{2}{*}{ CONSTRUCTION } & -0.580 & 0.078 & -0.101 & -1.187 \\
\hline & $(2.837)$ & $(1.021)$ & $(1.220)$ & $(1.454)$ \\
\hline \multirow{2}{*}{ MANUFACTURING } & -1.991 & 0.107 & -0.232 & -0.101 \\
\hline & (2.089) & $(0.779)$ & $(0.962)$ & (1.102) \\
\hline \multirow[t]{2}{*}{ TRADE } & -2.490 & 0.463 & -0.009 & -0.297 \\
\hline & (2.108) & $(0.769)$ & $(0.943)$ & $(1.166)$ \\
\hline \multirow[t]{2}{*}{ TRANSPORT } & -1.887 & -0.552 & -1.271 & 1.528 \\
\hline & (3.035) & (1.086) & (1.250) & (1.902) \\
\hline \multirow[t]{2}{*}{ SERVICES } & 0.423 & -0.185 & -0.658 & 0.010 \\
\hline & (3.492) & (1.021) & (1.212) & (1.310) \\
\hline \multirow[t]{2}{*}{ PROVISION } & -1.912 & -0.187 & -0.944 & -0.388 \\
\hline & $(2.141)$ & $(0.795)$ & $(1.001)$ & (1.136) \\
\hline \multirow[t]{2}{*}{ SOCIAL } & -1.103 & 0.465 & -0.299 & -1.307 \\
\hline & (2.403) & $(0.921)$ & (1.141) & (1.374) \\
\hline \multirow[t]{2}{*}{ GOVERNMENT } & -1.394 & 0.489 & -0.009 & 0.637 \\
\hline & $(2.226)$ & $(0.836)$ & (1.047) & (1.242) \\
\hline \multirow[t]{2}{*}{ OTHER } & -1.743 & 0.061 & -0.163 & 0.712 \\
\hline & $(2.413)$ & $(0.868)$ & $(1.052)$ & $(1.253)$ \\
\hline Observations & 331 & 331 & 331 & 331 \\
\hline R-squared & 0.653 & 0.801 & 0.510 & 0.554 \\
\hline
\end{tabular}

Notes: *** indicates statistically significant at $1 \%$ level, ** indicates statistically significant at $5 \%$ level, * indicates statistically significant at $10 \%$ level. Standard errors are in parentheses. Constant included in all regressions. 
Table A15: The effect corruption, as measured by the share of audited items found to involve corruption, and the informal economy has on GDP per-capita and income per-capita from different sources with fixed effects.

\begin{tabular}{|c|c|c|c|c|}
\hline & & & of Income i & \\
\hline & GDP_PC_10 & TOTAL & FORMAL & INFORMAL \\
\hline PROB_CORRUPT_2 & 0.061 & $0.240 * *$ & $0.245^{*}$ & 0.332 \\
\hline & $(0.419)$ & $(0.117)$ & $(0.143)$ & $(0.220)$ \\
\hline SIZE_INFORMAL & $-0.624 * *$ & $-0.257 * * *$ & 0.105 & $-0.252 * *$ \\
\hline & $(0.264)$ & $(0.064)$ & $(0.073)$ & $(0.126)$ \\
\hline POPULATION & 0.020 & $0.048 * * *$ & $0.051 * * *$ & $0.056^{* * *}$ \\
\hline & $(0.050)$ & $(0.009)$ & $(0.011)$ & $(0.016)$ \\
\hline URBAN & -0.087 & $-0.094 *$ & -0.043 & $-0.224 * *$ \\
\hline & $(0.177)$ & $(0.056)$ & $(0.068)$ & $(0.094)$ \\
\hline SCHOOL & $0.202 * * *$ & $0.122 * * *$ & $0.100 * * *$ & $0.056^{* *}$ \\
\hline & $(0.065)$ & $(0.019)$ & $(0.022)$ & $(0.026)$ \\
\hline DENSITY & $-0.118 * * *$ & $-0.027 * *$ & $-0.019 *$ & 0.012 \\
\hline & $(0.035)$ & $(0.010)$ & $(0.011)$ & $(0.013)$ \\
\hline DISTANCE_SP & -0.035 & -0.005 & 0.002 & $-0.081 * * *$ \\
\hline & $(0.062)$ & $(0.017)$ & $(0.020)$ & $(0.025)$ \\
\hline TEEN & -3.234 & -1.177 & -0.985 & $-2.558 *$ \\
\hline & $(2.876)$ & $(0.733)$ & $(0.852)$ & (1.378) \\
\hline WORK & $3.090 * *$ & 0.290 & 0.121 & 0.769 \\
\hline & $(1.543)$ & $(0.404)$ & $(0.478)$ & $(0.719)$ \\
\hline ELDER & $-7.102 * * *$ & $-1.746 * * *$ & $-0.962 * *$ & $-2.609 * * *$ \\
\hline & $(1.546)$ & $(0.426)$ & $(0.482)$ & $(0.756)$ \\
\hline AGRICULTURE & -0.593 & 0.379 & -0.328 & 0.448 \\
\hline & (1.446) & $(0.559)$ & $(0.589)$ & $(0.603)$ \\
\hline CONSTRUCTION & 1.466 & 0.883 & 0.279 & 0.769 \\
\hline & (1.949) & $(0.678)$ & (0.709) & $(0.758)$ \\
\hline MANUFACTURING & -0.101 & 0.453 & -0.202 & 0.645 \\
\hline & (1.515) & $(0.560)$ & $(0.591)$ & $(0.612)$ \\
\hline TRADE & -1.275 & 0.631 & -0.224 & 0.186 \\
\hline & (1.564) & $(0.573)$ & $(0.618)$ & (0.638) \\
\hline TRANSPORT & 0.231 & -0.277 & -0.997 & 0.945 \\
\hline & (2.597) & $(0.788)$ & $(0.838)$ & (1.179) \\
\hline SERVICES & 0.686 & 0.257 & -0.642 & 0.445 \\
\hline & $(2.101)$ & $(0.649)$ & $(0.677)$ & $(0.694)$ \\
\hline PROVISION & -0.998 & 0.200 & -0.849 & 0.830 \\
\hline & (1.556) & $(0.580)$ & $(0.625)$ & $(0.668)$ \\
\hline SOCIAL & -0.776 & 0.916 & -0.220 & -0.332 \\
\hline & $(1.867)$ & $(0.647)$ & $(0.677)$ & $(0.842)$ \\
\hline GOVERNMENT & -0.426 & 0.463 & -0.306 & -0.094 \\
\hline & (1.921) & $(0.599)$ & (0.679) & $(0.701)$ \\
\hline OTHER & -1.844 & 0.203 & -0.224 & 0.424 \\
\hline & $(1.860)$ & $(0.638)$ & $(0.703)$ & $(0.705)$ \\
\hline Observations & 434 & 434 & 434 & 434 \\
\hline R-squared & 0.664 & 0.855 & 0.634 & 0.801 \\
\hline
\end{tabular}

Notes: *** indicates statistically significant at $1 \%$ level, ** indicates statistically significant at $5 \%$ level, * indicates statistically significant at $10 \%$ level. Standard errors are in parentheses. Constant included in all regressions. 
Table A16: The effect corruption, as measured by the share of audited items found to involve corruption, and the informal economy has on GDP per-capita and income per-capita from different sources.

\begin{tabular}{|c|c|c|c|c|}
\hline & \multirow[b]{2}{*}{$G D P \_P C \_10$} & \multicolumn{3}{|c|}{ Types of Income in 2010} \\
\hline & & TOTAL & FORMAL & INFORMAL \\
\hline \multirow{2}{*}{ PROB_CORRUPT_2 } & 0.539 & $0.323 *$ & 0.170 & $0.649 * *$ \\
\hline & $(0.615)$ & $(0.164)$ & $(0.189)$ & $(0.317)$ \\
\hline \multirow[t]{2}{*}{ MISMANAGE } & 0.018 & 0.000 & $0.020^{* *}$ & $-0.034 * *$ \\
\hline & $(0.043)$ & $(0.008)$ & $(0.009)$ & $(0.015)$ \\
\hline \multirow[t]{2}{*}{ SIZE_INFORMAL } & -0.402 & $-0.250 * * *$ & 0.096 & -0.169 \\
\hline & $(0.283)$ & $(0.080)$ & $(0.089)$ & $(0.136)$ \\
\hline \multirow[t]{2}{*}{ POPULATION } & 0.037 & $0.057 * * *$ & $0.056 * * *$ & $0.054 * * *$ \\
\hline & $(0.047)$ & $(0.011)$ & $(0.012)$ & $(0.019)$ \\
\hline \multirow[t]{2}{*}{ URBAN } & -0.097 & -0.101 & -0.030 & $-0.199 *$ \\
\hline & $(0.193)$ & $(0.069)$ & $(0.084)$ & $(0.110)$ \\
\hline \multirow[t]{2}{*}{ SCHOOL } & $0.213 * * *$ & $0.124 * * *$ & $0.119 * * *$ & $0.067 * *$ \\
\hline & $(0.074)$ & $(0.023)$ & $(0.026)$ & $(0.031)$ \\
\hline \multirow[t]{2}{*}{ DENSITY } & $-0.120 * * *$ & $-0.030 * *$ & -0.019 & 0.018 \\
\hline & $(0.039)$ & $(0.012)$ & $(0.013)$ & $(0.015)$ \\
\hline \multirow[t]{2}{*}{ DISTANCE_SP } & -0.040 & 0.004 & 0.029 & $-0.075^{* *}$ \\
\hline & $(0.083)$ & $(0.022)$ & $(0.024)$ & $(0.034)$ \\
\hline \multirow[t]{2}{*}{ TEEN } & -4.330 & $-2.042 * *$ & -1.591 & -2.393 \\
\hline & (3.498) & $(0.886)$ & $(1.012)$ & (1.603) \\
\hline \multirow[t]{2}{*}{ WORK } & 2.868 & 0.114 & 0.075 & 0.745 \\
\hline & $(1.752)$ & $(0.456)$ & $(0.526)$ & $(0.798)$ \\
\hline \multirow[t]{2}{*}{ ELDER } & $-7.168 * * *$ & $-2.002 * * *$ & $-1.094 *$ & $-2.613 * * *$ \\
\hline & $(1.869)$ & $(0.521)$ & $(0.575)$ & $(0.895)$ \\
\hline \multirow[t]{2}{*}{ AGRICULTURE } & -2.597 & -0.208 & -0.688 & -0.146 \\
\hline & $(2.428)$ & $(0.879)$ & (1.078) & $(0.825)$ \\
\hline \multirow[t]{2}{*}{ CONSTRUCTION } & -2.099 & 0.300 & 0.102 & 0.470 \\
\hline & $(3.276)$ & (1.097) & $(1.331)$ & (1.124) \\
\hline \multirow[t]{2}{*}{ MANUFACTURING } & -2.596 & -0.157 & -0.628 & 0.075 \\
\hline & $(2.495)$ & $(0.874)$ & (1.078) & $(0.842)$ \\
\hline \multirow[t]{2}{*}{ TRADE } & -2.693 & 0.077 & -0.649 & -0.619 \\
\hline & $(2.388)$ & $(0.853)$ & (1.046) & $(0.826)$ \\
\hline \multirow[t]{2}{*}{ TRANSPORT } & -3.668 & -1.181 & -1.856 & 0.805 \\
\hline & (3.513) & (1.138) & $(1.341)$ & (1.465) \\
\hline \multirow[t]{2}{*}{ SERVICES } & 0.461 & -0.343 & -0.933 & -0.149 \\
\hline & (3.879) & $(1.007)$ & (1.187) & $(0.980)$ \\
\hline \multirow[t]{2}{*}{ PROVISION } & -2.833 & -0.569 & -1.440 & -0.108 \\
\hline & $(2.463)$ & $(0.882)$ & (1.089) & $(0.869)$ \\
\hline \multirow[t]{2}{*}{ SOCIAL } & -2.043 & 0.444 & -0.655 & -1.168 \\
\hline & $(2.820)$ & $(0.969)$ & (1.204) & (1.074) \\
\hline \multirow[t]{2}{*}{ GOVERNMENT } & -2.427 & -0.123 & -0.883 & -0.649 \\
\hline & (2.678) & $(0.914)$ & (1.150) & $(0.896)$ \\
\hline \multirow[t]{2}{*}{ OTHER } & -2.430 & -0.378 & -0.799 & -0.005 \\
\hline & $(2.757)$ & $(0.958)$ & $(1.150)$ & $(0.924)$ \\
\hline Observations & 331 & 331 & 331 & 331 \\
\hline R-squared & 0.706 & 0.856 & 0.653 & 0.804 \\
\hline
\end{tabular}

Notes: *** indicates statistically significant at $1 \%$ level, ** indicates statistically significant at $5 \%$ level, * indicates statistically significant at $10 \%$ level. Standard errors are in parentheses. Constant included in all regressions. 
Table A17: The effect corruption and the informal economy have on GDP per-capita and income per-capita; IV robustness checks.

\begin{tabular}{|c|c|c|c|c|}
\hline & $G D P \_P C \_04$ & TOTAL_OO & $G D P \_P C \_04$ & TOTAL_OO \\
\hline PROB_CORRUPT & $\begin{array}{c}-0.415^{* *} \\
(0.205)\end{array}$ & $\begin{array}{c}0.037 \\
(0.093)\end{array}$ & & \\
\hline PROB_CORRUPT_2 & & & $\begin{array}{l}-0.106 \\
(0.503)\end{array}$ & $\begin{array}{l}-0.094 \\
(0.209)\end{array}$ \\
\hline SIZE_INFORMAL & $\begin{array}{c}-1.543 * * * \\
(0.545)\end{array}$ & $\begin{array}{c}0.273 \\
(0.248)\end{array}$ & $\begin{array}{c}-1.554 * * * \\
(0.542)\end{array}$ & $\begin{array}{c}0.284 \\
(0.247)\end{array}$ \\
\hline POPULATION & $\begin{array}{c}0.033 \\
(0.039)\end{array}$ & $\begin{array}{c}0.066 * * * \\
(0.015)\end{array}$ & $\begin{array}{c}0.040 \\
(0.040)\end{array}$ & $\begin{array}{c}0.065 * * * \\
(0.015)\end{array}$ \\
\hline$U R B A N$ & $\begin{array}{c}0.013 \\
(0.214)\end{array}$ & $\begin{array}{c}-0.218 * * * \\
(0.084)\end{array}$ & $\begin{array}{l}-0.013 \\
(0.214)\end{array}$ & $\begin{array}{c}-0.215^{* *} \\
(0.084)\end{array}$ \\
\hline SCHOOL & $\begin{array}{c}0.164 * * * \\
(0.057)\end{array}$ & $\begin{array}{c}0.244 * * * \\
(0.026)\end{array}$ & $\begin{array}{c}0.167 * * * \\
(0.058)\end{array}$ & $\begin{array}{c}0.242 * * * \\
(0.027)\end{array}$ \\
\hline DENSITY & $\begin{array}{c}-0.124 * * * \\
(0.030)\end{array}$ & $\begin{array}{c}-0.054 * * * \\
(0.010)\end{array}$ & $\begin{array}{c}-0.126 * * * \\
(0.031)\end{array}$ & $\begin{array}{c}-0.053 * * * \\
(0.010)\end{array}$ \\
\hline DISTANCE_SP & $\begin{array}{c}0.028 \\
(0.053)\end{array}$ & $\begin{array}{c}-0.069 * * * \\
(0.018)\end{array}$ & $\begin{array}{c}0.025 \\
(0.052)\end{array}$ & $\begin{array}{c}-0.070 * * * \\
(0.017)\end{array}$ \\
\hline TEEN & $\begin{array}{l}-3.602 \\
(2.208)\end{array}$ & $\begin{array}{c}-4.438 * * * \\
(1.083)\end{array}$ & $\begin{array}{c}-3.746^{*} \\
(2.203)\end{array}$ & $\begin{array}{c}-4.370 * * * \\
(1.090)\end{array}$ \\
\hline WORK & $\begin{array}{c}4.727 * * * \\
(1.240)\end{array}$ & $\begin{array}{c}-1.493 * * * \\
(0.556)\end{array}$ & $\begin{array}{c}4.728 * * * \\
(1.251)\end{array}$ & $\begin{array}{c}-1.490 * * * \\
(0.557)\end{array}$ \\
\hline ELDER & $\begin{array}{c}-5.750 * * * \\
(1.281)\end{array}$ & $\begin{array}{c}-4.493 * * * \\
(0.533)\end{array}$ & $\begin{array}{c}-5.848 * * * \\
(1.273)\end{array}$ & $\begin{array}{c}-4.473 * * * \\
(0.531)\end{array}$ \\
\hline AGRICULTURE & $\begin{array}{l}-0.118 \\
(1.191)\end{array}$ & $\begin{array}{l}-0.263 \\
(0.661)\end{array}$ & $\begin{array}{l}-0.197 \\
(1.207)\end{array}$ & $\begin{array}{l}-0.261 \\
(0.670)\end{array}$ \\
\hline CONSTRUCTION & $\begin{array}{c}0.947 \\
(1.603)\end{array}$ & $\begin{array}{c}0.064 \\
(0.818)\end{array}$ & $\begin{array}{c}0.437 \\
(1.546)\end{array}$ & $\begin{array}{c}0.107 \\
(0.810)\end{array}$ \\
\hline MANUFACTURING & $\begin{array}{l}-0.324 \\
(1.261)\end{array}$ & $\begin{array}{c}0.173 \\
(0.680)\end{array}$ & $\begin{array}{l}-0.433 \\
(1.280)\end{array}$ & $\begin{array}{c}0.185 \\
(0.690)\end{array}$ \\
\hline TRADE & $\begin{array}{l}-1.589 \\
(1.450)\end{array}$ & $\begin{array}{l}-0.138 \\
(0.676)\end{array}$ & $\begin{array}{l}-1.560 \\
(1.471)\end{array}$ & $\begin{array}{l}-0.136 \\
(0.689)\end{array}$ \\
\hline TRANSPORT & $\begin{array}{c}0.831 \\
(2.351)\end{array}$ & $\begin{array}{l}2.320^{* * *} \\
(1.070)\end{array}$ & $\begin{array}{c}0.767 \\
(2.392)\end{array}$ & $\begin{array}{l}2.359 * * \\
(1.072)\end{array}$ \\
\hline SERVICES & $\begin{array}{c}0.617 \\
(2.039)\end{array}$ & $\begin{array}{c}0.253 \\
(0.836)\end{array}$ & $\begin{array}{c}0.594 \\
(2.052)\end{array}$ & $\begin{array}{c}0.265 \\
(0.852)\end{array}$ \\
\hline PROVISION & $\begin{array}{l}-0.586 \\
(1.355)\end{array}$ & $\begin{array}{l}-1.025 \\
(0.718)\end{array}$ & $\begin{array}{l}-0.649 \\
(1.375)\end{array}$ & $\begin{array}{l}-1.031 \\
(0.725)\end{array}$ \\
\hline SOCIAL & $\begin{array}{c}0.684 \\
(1.596)\end{array}$ & $\begin{array}{c}0.558 \\
(0.808)\end{array}$ & $\begin{array}{c}0.679 \\
(1.616)\end{array}$ & $\begin{array}{c}0.566 \\
(0.818)\end{array}$ \\
\hline GOVERNMENT & $\begin{array}{c}0.992 \\
(1.533)\end{array}$ & $\begin{array}{c}0.220 \\
(0.737)\end{array}$ & $\begin{array}{c}1.013 \\
(1.554)\end{array}$ & $\begin{array}{c}0.206 \\
(0.747)\end{array}$ \\
\hline OTHER & $\begin{array}{l}-2.017 \\
(1.464)\end{array}$ & $\begin{array}{c}0.043 \\
(0.793)\end{array}$ & $\begin{array}{l}-2.090 \\
(1.474)\end{array}$ & $\begin{array}{c}0.056 \\
(0.807)\end{array}$ \\
\hline Observations & 404 & 404 & 404 & 404 \\
\hline R-squared & 0.639 & 0.766 & 0.636 & 0.764 \\
\hline J-Statistic & 0.321 & 0.394 & 0.369 & 0.332 \\
\hline
\end{tabular}

Notes: *** indicates statistically significant at $1 \%$ level, ** indicates statistically significant at $5 \%$ level, * indicates statistically significant at $10 \%$ level. Standard errors are in parentheses. Constant included in all regressions. F-Statistic 22.437 with PROB_CORRUPT and 22.206 with PROB_CORRUPT_2. 
Table A18: The effect corruption and the informal economy have on GDP per-capita and income per-capita; IV robustness checks.

\begin{tabular}{|c|c|c|c|c|}
\hline & $G D P \_P C_{-} 10$ & TOTAL_10 & $G D P \_P C_{-} 10$ & TOTAL_10 \\
\hline PROB_CORRUPT & $\begin{array}{c}-0.461 * * \\
(0.200)\end{array}$ & $\begin{array}{c}0.053 \\
(0.064)\end{array}$ & & \\
\hline PROB_CORRUPT_2 & & & $\begin{array}{l}-0.304 \\
(0.421)\end{array}$ & $\begin{array}{c}0.154 \\
(0.135)\end{array}$ \\
\hline SIZE_INFORMAL & $\begin{array}{c}-1.152 * * \\
(0.519)\end{array}$ & $\begin{array}{l}-0.014 \\
(0.192)\end{array}$ & $\begin{array}{c}-1.145 * * \\
(0.517)\end{array}$ & $\begin{array}{l}-0.027 \\
(0.191)\end{array}$ \\
\hline POPULATION & $\begin{array}{c}0.035 \\
(0.039)\end{array}$ & $\begin{array}{c}0.048 * * * \\
(0.011)\end{array}$ & $\begin{array}{c}0.042 \\
(0.040)\end{array}$ & $\begin{array}{c}0.048^{* * *} * \\
(0.010)\end{array}$ \\
\hline$U R B A N$ & $\begin{array}{l}-0.096 \\
(0.191)\end{array}$ & $\begin{array}{c}-0.123 * * \\
(0.061)\end{array}$ & $\begin{array}{l}-0.123 \\
(0.192)\end{array}$ & $\begin{array}{c}-0.122 * * \\
(0.060)\end{array}$ \\
\hline SCHOOL & $\begin{array}{c}0.188 * * * \\
(0.056)\end{array}$ & $\begin{array}{c}0.176 * * * \\
(0.021)\end{array}$ & $\begin{array}{c}0.188 * * * \\
(0.057)\end{array}$ & $\begin{array}{c}0.177 * * * \\
(0.022)\end{array}$ \\
\hline DENSITY & $\begin{array}{c}-0.099 * * * \\
(0.026)\end{array}$ & $\begin{array}{c}-0.047 * * * \\
(0.009)\end{array}$ & $\begin{array}{c}-0.101 * * * \\
(0.027)\end{array}$ & $\begin{array}{c}-0.048 * * * \\
(0.009)\end{array}$ \\
\hline DISTANCE_SP & $\begin{array}{c}0.006 \\
(0.048)\end{array}$ & $\begin{array}{c}-0.027^{*} \\
(0.014)\end{array}$ & $\begin{array}{l}-0.000 \\
(0.048)\end{array}$ & $\begin{array}{c}-0.024^{*} \\
(0.014)\end{array}$ \\
\hline TEEN & $\begin{array}{l}-0.931 \\
(2.070)\end{array}$ & $\begin{array}{c}-1.804 * * \\
(0.826)\end{array}$ & $\begin{array}{l}-0.993 \\
(2.075)\end{array}$ & $\begin{array}{c}-1.860 * * \\
(0.828)\end{array}$ \\
\hline WORK & $\begin{array}{c}4.934 * * * \\
(1.160)\end{array}$ & $\begin{array}{c}0.142 \\
(0.394)\end{array}$ & $\begin{array}{c}4.940 * * * \\
(1.167)\end{array}$ & $\begin{array}{c}0.139 \\
(0.394)\end{array}$ \\
\hline ELDER & $\begin{array}{c}-4.842 * * * \\
(1.189)\end{array}$ & $\begin{array}{c}-3.374 * * * \\
(0.375)\end{array}$ & $\begin{array}{c}-4.932 * * * \\
(1.192)\end{array}$ & $\begin{array}{c}-3.376 * * * \\
(0.374)\end{array}$ \\
\hline AGRICULTURE & $\begin{array}{c}0.094 \\
(1.308)\end{array}$ & $\begin{array}{c}0.711 \\
(0.568)\end{array}$ & $\begin{array}{l}-0.000 \\
(1.340)\end{array}$ & $\begin{array}{c}0.727 \\
(0.552)\end{array}$ \\
\hline CONSTRUCTION & $\begin{array}{c}2.478 \\
(1.778)\end{array}$ & $\begin{array}{c}0.764 \\
(0.699)\end{array}$ & $\begin{array}{l}1.908 \\
(1.714)\end{array}$ & $\begin{array}{c}0.832 \\
(0.664)\end{array}$ \\
\hline MANUFACTURING & $\begin{array}{l}-0.149 \\
(1.356)\end{array}$ & $\begin{array}{c}0.924 \\
(0.573)\end{array}$ & $\begin{array}{l}-0.265 \\
(1.391)\end{array}$ & $\begin{array}{l}0.934^{*} \\
(0.559)\end{array}$ \\
\hline TRADE & $\begin{array}{l}-1.931 \\
(1.473)\end{array}$ & $\begin{array}{l}0.944^{*} \\
(0.574)\end{array}$ & $\begin{array}{l}-1.892 \\
(1.506)\end{array}$ & $\begin{array}{l}0.935^{*} \\
(0.561)\end{array}$ \\
\hline TRANSPORT & $\begin{array}{l}1.975 \\
(2.228)\end{array}$ & $\begin{array}{c}0.883 \\
(0.868)\end{array}$ & $\begin{array}{c}1.964 \\
(2.283)\end{array}$ & $\begin{array}{c}0.845 \\
(0.860)\end{array}$ \\
\hline SERVICES & $\begin{array}{c}0.337 \\
(1.868)\end{array}$ & $\begin{array}{c}0.631 \\
(0.723)\end{array}$ & $\begin{array}{c}0.329 \\
(1.902)\end{array}$ & $\begin{array}{c}0.621 \\
(0.703)\end{array}$ \\
\hline PROVISION & $\begin{array}{l}-0.321 \\
(1.471)\end{array}$ & $\begin{array}{c}0.396 \\
(0.604)\end{array}$ & $\begin{array}{l}-0.410 \\
(1.501)\end{array}$ & $\begin{array}{c}0.419 \\
(0.588)\end{array}$ \\
\hline SOCIAL & $\begin{array}{c}0.304 \\
(1.603)\end{array}$ & $\begin{array}{l}1.208^{*} \\
(0.684)\end{array}$ & $\begin{array}{c}0.312 \\
(1.641)\end{array}$ & $\begin{array}{l}1.199 * \\
(0.669)\end{array}$ \\
\hline GOVERNMENT & $\begin{array}{c}0.720 \\
(1.579)\end{array}$ & $\begin{array}{l}1.067^{*} \\
(0.610)\end{array}$ & $\begin{array}{c}0.723 \\
(1.612)\end{array}$ & $\begin{array}{l}1.081 * \\
(0.595)\end{array}$ \\
\hline OTHER & $\begin{array}{l}-0.961 \\
(1.580)\end{array}$ & $\begin{array}{c}0.865 \\
(0.638)\end{array}$ & $\begin{array}{l}-1.030 \\
(1.604)\end{array}$ & $\begin{array}{c}0.865 \\
(0.623)\end{array}$ \\
\hline Observations & 404 & 404 & 404 & 404 \\
\hline R-squared & 0.628 & 0.789 & 0.625 & 0.790 \\
\hline J-Statistic & 0.173 & 0.672 & 0.192 & 0.755 \\
\hline
\end{tabular}

Notes: *** indicates statistically significant at $1 \%$ level, ** indicates statistically significant at $5 \%$ level, * indicates statistically significant at $10 \%$ level. Standard errors are in parentheses. Constant included in all regressions. F-Statistic 22.437 with PROB_CORRUPT and 22.206 with PROB_CORRUPT_2. 